\title{
The labour market and income distribution in Colombia in the 1990s
}

\section{José Antonio Ocampo}

Executive Secretary of the

Economic Commission for Latin

America and the Caribbean (ECLAC)

jaocampo@eclac.cl

Fabio Sánchez

Research Professor,

Faculty of Economics, Universidad de los Andes, Bogotá

fasanche@uniandes.edu.co

\section{Camilo Ernesto Tovar}

Consultant to the Executive

Secretary of ECLAC

cetovar@students.wisc.edu
This article analyses the behaviour of the Colombian labour market and the changes it underwent during the 1990s. It begins by outlining the reforms carried out in that country and summarizing macroeconomic developments and changes in the production structure in the 1990s. Then it uses data available from household surveys to analyse the dynamic of the labour market by economic sector, educational level and occupational position. After briefly describing the latest advances in research into income distribution in Colombia, it then shows the results of simulation exercises carried out to determine the effects of the changes observed in labour market conditions (sectoral structure of employment, relative wages, unemployment and labour force participation) on income distribution and poverty, both for the country as a whole and for the urban and rural sectors separately. The article concludes that the ability of the economy to generate employment has deteriorated markedly, and that this deterioration has affected lower-skilled workers most of all. 


\section{Introduction}

In the 1990s Colombia, like other Latin American countries, was in the throes of an intense process of structural reform. On the external front, this process had elements in common with developments elsewhere in the region (trade reform and a new openness to foreign direct investment), but there were also points of difference, particularly the continuation of active external debt management. This was accompanied by moderate labour market reform and a more ambitious reform to the social security system, the latter being part of a wider move to allow the private sector to become involved in areas traditionally reserved to the State. The independence given to the Bank of the Republic (central bank) and a series of reforms designed to increase competition among financial intermediaries and improve prudential regulation and supervision were the most striking developments in the monetary and financial field. The greatest difference between Colombia and the region in general, however, was the way these economic liberalization processes were combined with substantial growth in the size of the public sector, the purpose of which was to increase the provision of social services. Despite a rise in public revenue that was also substantial, this tendency resulted in a deterioration of the fiscal position, showing how difficult it has been for the Colombian State to reconcile economic liberalization with a more active social policy.

\section{II}

\section{The reforms}

The structural reform or economic opening process, as it is known in Colombia, began at the end of Barco's term in office and was pursued most vigorously under

$\square$ This article was prepared for the UNDP-ECLAC-IDB project "Liberalización de la balanza de pagos: efectos sobre el empleo, la distribución, la pobreza y el crecimiento". Section V was written in collaboration with Jairo Núñez. The comments made on previous versions of this text by Jaime Aristy, Samuel Morley, Roberto Paes de Barros, Juan Carlos Ramírez, Lance Taylor, Rob Vos and other project participants are gratefully acknowledged, as is the assistance provided by Piedad Urdinola.
In terms of productive activity, in the 1990s the economy grew at moderate rates and was less stable than it had been in the past, particularly as regards the behaviour of aggregate demand, while inflation gradually declined. As this process went on, those sectors that were more exposed to external competition weakened markedly and the situation in the labour market deteriorated as its composition changed, a process that was accompanied by a fall in job creation, particularly in those production sectors, such as agriculture and manufacturing industry, that were more open to international competition. This recomposition of the labour market entailed the shedding of low-skilled jobs, and this was not fully offset by the increase in the number of new jobs for more highly educated workers. This suggests that the technical changes which have taken place since the early 1990s have given greater weight to processes that are more intensive in better educated labour, while lessening the need for labour of every educational level. The changes in the labour market have had adverse effects on income distribution in urban areas, and in the country as a whole these have outweighed the beneficial effects felt in rural ones. The latter have been mainly affected by an adverse shock in the rural-urban terms of trade and the resultant crisis in commercial farming.
Gaviria (1990-1994). With some slight modifications, the Samper Government (1994-1998) deepened the reforms and the current one (Pastrana, 1998-2002) is continuing with them. The main feature of this process was the liberalization of external transactions, i.e., the trade, currency and foreign direct investment (FDI) regimes. These reforms were accompanied not just by economic growth but also by a change in the structure of the public sector and a recasting of its functions, all part of the profound reform of the State that followed the approval of a new political charter in 1991. In

THE LABOUR MARKET AND INCOME DISTRIBUTION IN COLOMBIA IN THE 1990S • JOSE ANTONIO OCAMPO, FABIO SANCHEZ 
addition to these developments, mention should be made of the 1990 reform that brought a degree of flexibility to the labour market and a more ambitious reform to the social security system that took place in 1993 (Ocampo, 1998).

\section{Liberalization of external transactions}

Trade liberalization has had two basic components: the freeing up of imports and the signing of a wide range of integration and free trade agreements. Both the tariff reduction programme put into effect by the Barco Government in February 1990 and the more ambitious one announced a few months later by the Gaviria Government proposed a gradual reduction in tariffs (over five and three years, respectively) following rapid dismantling of quantitative restrictions on imports. However, a series of macroeconomic complications led the authorities to speed up the tariff reduction process, which culminated in August 1991. In this period of a year and a half direct controls on imports were virtually done away with, the average tariff was reduced from $44 \%$ to $12 \%$ and export incentives were cut from $19 \%$ in 1990 to $6 \%$ in 1993 . To mitigate the effects of fluctuations in international prices, a price band system (variable tariffs) was adopted for agriculture. In conjunction with this, safeguard and unfair competition rules were designed, and generally moderate use was made of these over the following years.

The increased vigour of the trade integration process, meanwhile, was the result of decisions taken in 1989, when the presidents of the Andean Group (which subsequently became the Andean Community) agreed to revitalize, deepen and reorient the subregional integration process. Subsequent meetings led to an agreement, in 1991, to create a free trade zone, which was to come into force in 1992. In that year, though, it was only possible to create a free trade area with Venezuela and Bolivia, which Ecuador also joined a year later. In late 1994 a common external tariff was adopted with certain exceptions, although in practice this applies only to Colombia, Venezuela and, with numerous exceptions, Ecuador. This process was complemented by the signing of the free trade agreement with Chile in 1993 and Mexico (the Group of Three, which also includes Venezuela) in 1994, and the commencement of Andean Community-Mercosur negotiations in subsequent years, among other instances.

The main components of the capital account liberalization process were foreign exchange reform and liberalization of inward FDI. The latter process began in the late 1980s and was completed in 1990 and 1991, when all restrictions on inward FDI were abolished, except in the areas of security, toxic wastes and largescale mining investments. At the same time, the rules governing Colombian investment abroad were also liberalized. Over the following years the country began to sign up to agreements providing mutual protection for foreign investment.

The foreign exchange reform of 1991, meanwhile, decentralized the handling of foreign currency transactions by authorizing intermediaries to carry these out without prior controls being applied by the Bank of the Republic. Nonetheless, many transactions continued to be regulated, and they still had to be channelled through financial intermediaries legally authorized to operate in the market. Where capital transactions were concerned, the ultimate use of loans (investment and foreign trade operations) continued to be strictly controlled. Only in February 1992 did it become permissible for the first time to take out shortterm loans abroad to finance working capital. The foreign exchange reform of September 1993 authorized financial intermediaries to make foreign currency loans to domestic companies regardless of the use made of such credits, at the same time replacing the old regulatory system by one based on an obligation for foreign currency borrowers to lodge a deposit or reserve with the Bank of the Republic. The purpose of this was to oversee the scale and composition of capital flows. ${ }^{1}$ The loan period after which the reserve requirement became applicable and the amount of this reserve were tightened up in 1994, eased in 1996 and tightened up again in 1997. In May of that year the country introduced a simpler system of controls on foreign borrowing, more similar to the one used by Chile throughout the 1990s, making it obligatory for a deposit to be lodged for all loans. The size of the tax implicit in this capital regime was consistently higher than in the Chilean system during the years of abundant foreign capital (an average of $13.6 \%$ and 6.4\% in 1994-1998 for credits of 12 and 36 months, respectively). ${ }^{2}$ During the crisis of the latter part of the decade the size of this

\footnotetext{
${ }^{1}$ For a detailed analysis of regulations applying to capital flows in the 1990s, and of the effectiveness of these, see Ocampo and Tovar (1999) and Villar and Rincón (2000).

${ }^{2}$ In the early months of 1997 there was also a short period during which capital flows were taxed explicitly. This was declared unenforceable by the Constitutional Court in view of the procedure used to order it (the constitutional formula of the "economic emergency").
} 
deposit was gradually lowered, until the requirement was abolished in early 2000.

\section{Growth, structural change and the redefining of State functions}

The 1991 Constitution and other political decisions taken over the course of the decade had a significant impact on the structure of the State, and this changed the dynamic of the public finances. As we noted in the introduction, the way this dynamic has combined with the structural reform process sets Colombia apart from the rest of Latin America. The country's singularity lies in the fact that the process of opening up and deregulating the economy has been accompanied by an increase in the size of the State, which grew from $30 \%$ of GDP in 1990 to $38 \%$ by the end of the 1990 s.

The reforms that had the greatest fiscal effect were the increase in transfers to departments and municipalities to finance higher social investment and the widening of social security coverage. It has been estimated that the 1991 Constitution and the laws that built on it (particularly law 60 of 1993, which put the new system of transfers into effect, and law 100 of 1993, which created the new social security system) permanently allocated to those ends national government expenditure equivalent to just over 4\% of GDP (Ocampo, 1997). This is the main source of the overall increase in central government spending, excluding interest. Despite partial privatization, the social security reform likewise gave rise to a parallel increase in the benefits provided by the relevant public bodies.

Rapid spending growth was largely offset by higher tax revenues, owing especially to higher central government taxes, higher social security contributions and, to a lesser extent, municipal taxes. In fact, the change in the tax structure resulting from trade liberalization, which made the country less dependent on external revenue, was counterbalanced by a series of tax reforms (1990, 1992, 1995, 1997, 1998 and one currently under way in 2000) which have served to finance the higher spending, albeit only in part. Since the mid1990s the budget deficit, particularly the central government one, has tended to increase, so that it stood at $3.9 \%$ of GDP in 1998 and $5.2 \%$ of GDP in 1999 (in the latter year it reflects the fall-off in revenue resulting from the recession). Taking the public sector in the aggregate, the deficit stood at $3.1 \%$ and $4.5 \%$ of GDP in the years referred to. This higher deficit, and the constant need to modify the country's tax structure, reflect the difficulties the Colombian State has encountered in reconciling an open economy with a more active social policy.

The growth in the size of the State was accompanied by a marked change in its structure, the main features of which were far-reaching fiscal decentralization and the opening up to the private sector of areas of the economy that had traditionally been the preserve of the State. The transfer of national revenue to the departments and, in particular, to the municipalities, has been the fastest growing component in national government outlays. Meanwhile, it is the spending of the municipalities, together with that of the social security system, that has seen the highest rate of growth in the public sector as a whole. Privatization, the franchising of infrastructure projects and the opening up in general of the infrastructure and social security sectors to private investment are the most notable developments on this second front. This process was accompanied by the creation of stronger regulatory and supervisory institutions in the infrastructure, social security and financial sectors. In all these fields, however, what the implicit model chosen entails in practice is the maintenance of a large number of public companies and organizations that complement the private sector in some fields while competing with it in others. On the financial front, it should be added that in the early part of the decade a reform was carried out with a view to increasing competition among different types of intermediaries, some of the organizations that had been nationalized during the financial crisis of the early 1980s were privatized and the sector was fully opened up to FDI. The 1991 Constitution, meanwhile, made the Bank of the Republic fully independent for the purposes of monetary and exchange rate management.

\section{Labour market and social security reform}

The 1990 labour market reform partially freed up the labour market while giving greater protection to union rights. The general thrust of this reform was to put into effect many of the proposals made a few years previously by the Employment Commission (Colombia, Contraloría General de la República, 1986). The most important reforms on the first front were the provisions that made temporary hiring more flexible, those facilitating dismissal for workers with more than ten years of service (in exchange for a higher redundancy payment, and subject in any event to the requirement that "just cause" be shown for the dismissal), the adoption of a wage system integrating all remuneration for higher-income workers (those earning more than

THE LABOUR MARKET AND INCOME DISTRIBUTION IN COLOMBIA IN THE 1990S • JOSE ANTONIO OCAMPO, FABIO SANCHEZ 
10 times the minimum wage) and the elimination of the excess costs involved in the previous unemployment regime. This social benefit provided for workers to be paid one month's wages per year of service when they left the company; however, the system for liquidating withdrawals from the worker's account meant that the cost rose rapidly as years of service increased. The reform replaced this system with one that obliged new workers to pay into unemployment funds and that enabled companies to negotiate with existing workers with a view to transferring them to the new system, subject to compensation. Besides these changes, which were designed to make the labour market more flexible, it strengthened the right to unionization and complemented this with legal instruments to make it effective.
In fact, the results in terms of greater labour market flexibility were not striking, largely owing to the countervailing effects of the subsequent 1993 social security reform. The changes made to the legislation on temporary contracts were undoubtedly one of the factors that led to the share of temporary employment in total urban employment increasing from $15.8 \%$ to $20 \%$ between 1990 and 1997 (ILO, 1998). Nonetheless, this increase in flexibility and reduction of the excessive costs associated with the old unemployment system were offset by the growing cost of taking on new workers and by the rise in redundancy payments. The former was a direct result of the social security reform, which raised the contribution costs payable by the company from $13.5 \%$ to $25.5 \%$ (of which $13.5 \%$ now goes to pensions and the other $12 \%$ to health), ${ }^{3}$ increasing social costs from $47 \%$ to $59.4 \%$ of basic wages.

\section{III}

\section{Macroeconomic developments}

The 1990s were characterized by pronounced "stop and go" cycles in macroeconomic policy. Although these cycles were partly driven by external shocks, both positive and negative, particularly those deriving from the international capital market, others originated in domestic events.

The decade began in the midst of rising inflationary pressures. These were addressed by means of a strong adjustment package, brought in towards the end of 1990, which included a severe monetary contraction, revaluation, a moderate fiscal adjustment (table 1) and faster implementation of the trade liberalization programme. This package slowed economic growth, halted the inflationary trend and sharply improved the current account of the balance of payments.

As a result of the heavy pressure placed on international reserves and the growing quasifiscal costs to which these contractionary monetary measures gave rise over the course of 1991, the Bank of the Republic decided to speed up the revaluation process and drastically cut interest rates. At the same time, rapid growth in tax revenue led to strong growth in public spending, the overall fiscal position remaining in balance. The combined result of these policies was a rise in internal and external borrowing which caused aggregate domestic demand to grow rapidly in 1992-1994, more rap- idly in fact than at any other time in Colombia's postwar economic history. Economic activity and productive investment boomed, but against the background of a sharp deterioration in the current account balance. The biggest exception in terms of production was agriculture, which struggled to cope with trade liberalization right from the beginning of the decade, particularly as international prices, especially for coffee, were low. Inflation was kept in check -and even declined somewhat further during the first part of the upturnthanks to currency appreciation and rapid import growth, but there were clear signs of inflation in domestic asset prices (real estate and stock market assets).

Monetary policy became increasingly tight over the course of 1994 and 1995. The strong controls on foreign borrowing adopted in 1994 also helped to slow private demand growth and prevented this tight monetary policy giving rise to a further currency appreciation in real terms. Aggregate demand began to slow in 1995 and, more sharply, in 1996, giving rise to a pronounced fall-off in production activity and halting the deterioration in the current account of the balance of

\footnotetext{
${ }^{3}$ See ILO (1998) and Reina and Yanovich (1998).
}

THE LABOUR MARKET AND INCOME DISTRIBUTION IN COLOMBIA IN THE 1990S • JOSE ANTONIO OCAMPO, FABIO SANCHEZ AND CAMILO ERNESTO TOVAR 
Colombia: Policy variables and overview of results

\begin{tabular}{|c|c|c|c|c|c|c|c|c|c|c|c|c|c|c|}
\hline & $\begin{array}{l}1975- \\
1979\end{array}$ & $\begin{array}{l}1980- \\
1985\end{array}$ & $\begin{array}{l}1986- \\
1990\end{array}$ & $\begin{array}{l}1991- \\
1999\end{array}$ & 1990 & 1991 & 1992 & 1993 & 1994 & 1995 & 1996 & 1997 & 1998 & 1999 \\
\hline Real exchange rate (1994=100) & 81.0 & 73.0 & 103.0 & 103.1 & 114.9 & 113.0 & 106.8 & 107.5 & 100.0 & 102.3 & 98.8 & 93.3 & 98.3 & 108.2 \\
\hline \multicolumn{15}{|l|}{ Real interest rate } \\
\hline Deposit rate (90 days) & & 10.3 & 6.4 & 6.2 & 4.9 & 4.8 & -0.4 & 2.5 & 5.5 & 9.3 & 8.2 & 4.8 & 11.8 & 8.8 \\
\hline Average lending rate & & & 14.1 & 14.9 & 12.6 & 12.9 & 8.1 & 10.9 & 14.4 & 18.2 & 17.7 & 13.6 & 20.7 & 17.4 \\
\hline \multicolumn{15}{|c|}{ Total government expenditure (\% of GDP) } \\
\hline DANE & 20.3 & 28.1 & 30.1 & 31.7 & 30.4 & 31.0 & 31.1 & 31.3 & 31.3 & 34.1 & & & & \\
\hline $\begin{array}{l}\text { Bank of the Republic } \\
\text { (net of transfers) }\end{array}$ & & & & 31.9 & 30.4 & 31.8 & 31.0 & 31.3 & 31.4 & 34.0 & & & & \\
\hline Ministry of Finance & & & & & & & & & 30.3 & 32.0 & 35.8 & 37.2 & 36.0 & \\
\hline \multicolumn{15}{|l|}{ Overall budget deficit or surplus, } \\
\hline Central Government & -0.2 & -3.3 & -0.9 & -2.2 & -0.6 & 0.4 & 0.1 & -0.3 & -1.6 & -2.6 & -4.3 & -4.3 & -5.6 & -5.9 \\
\hline Rest of the public sector & -1.3 & -2.0 & -0.6 & 0.7 & 0.2 & -0.4 & -0.3 & 0.3 & 1.7 & 2.3 & 2.3 & 0.5 & 1.7 & 0.6 \\
\hline GDP growth & 5.0 & 2.6 & 4.6 & 2.6 & 4.3 & 2.0 & 4.0 & 5.4 & 5.8 & 5.2 & 2.1 & 3.4 & 0.4 & -4.5 \\
\hline Value added by tradables & 4.9 & 1.8 & 5.7 & 0.9 & 5.1 & 2.2 & 0.8 & 2.1 & 1.3 & 5.8 & -0.6 & 0.9 & 1.4 & -5.5 \\
\hline Value added by non-tradables & 5.1 & 3.2 & 3.7 & 3.4 & 3.2 & 2.0 & 5.4 & 5.3 & 7.8 & 6.4 & 4.8 & 4.7 & -1.2 & -4.4 \\
\hline Aggregate domestic demand & 4.8 & 2.4 & 3.4 & 8.5 & 2.3 & 0.1 & 10.0 & 12.1 & 12.0 & 5.8 & 1.1 & 4.0 & -1.1 & -8.3 \\
\hline Inflation (CPI end of period) & 23.9 & 26.7 & 26.3 & 20.2 & 32.4 & 26.8 & 25.1 & 22.6 & 22.6 & 19.5 & 21.6 & 17.7 & 16.7 & 9.2 \\
\hline \multicolumn{15}{|l|}{ Exports } \\
\hline (\% of GDP at 1975 prices) & 15.0 & 14.4 & 18.5 & 22.9 & 20.7 & 22.7 & 23.1 & 23.3 & 22.0 & 21.7 & 23.3 & 23.2 & 23.1 & 24.2 \\
\hline \multicolumn{15}{|c|}{$\begin{array}{l}\text { External balances } \\
\text { (\% of GDP at } 1994 \text { par exchange rate) }\end{array}$} \\
\hline Trade balance & 3.5 & -3.1 & 3.9 & -1.2 & 4.3 & 6.2 & 2.3 & -2.8 & -3.3 & -3.3 & -2.9 & -3.2 & -4.7 & 0.4 \\
\hline Current account & 1.5 & -6.8 & 0.3 & -3.1 & 1.2 & 4.9 & 1.7 & -3.7 & -5.2 & -5.6 & -5.6 & -6.5 & -6.2 & -1.2 \\
\hline $\begin{array}{l}\text { Gross fixed capital formation } \\
\text { (\% of GDP at } 1975 \text { prices) }\end{array}$ & 15.6 & 17.1 & 15.5 & 16.7 & 14.0 & 12.9 & 13.9 & 18.0 & 20.7 & 19.8 & 19.1 & 18.1 & 16.0 & 11.8 \\
\hline
\end{tabular}

Sources: Bank of the Republic, National Department of Statistics (DANE) and National Department of Planning (DNP).

payments. The continuing surge in public expenditure was the main factor underlying growth in those years.

Cuts in interest rates over the course of 1996 helped to reactivate private demand and production activity in 1997. Public spending did not contribute to this upturn; rather, it was during those years that the first steps began to be taken to curb growing expenditure by the national Government, given the evidence of rapid growth in the budget deficit. Strong control of external borrowing curbed the tendency towards appreciation of the currency that had made itself felt during 1996 (this being reflected in the annual averages for 1997), but there was a further moderate deterioration in the current account.

The upturn was short-lived, owing to the effects of the international crisis and the measures taken to deal with it, at a time when the external accounts and the fiscal situation were weak. The tight monetary policy which was adopted to deal with the crisis was effective in gradually lowering the real exchange rate through a series of changes to the exchange rate band, reducing aggregate demand, improving the external accounts and lowering inflation, but at the cost of bringing on the worst recession in Colombian history and accelerating the deterioration of the financial system portfolio. Paradoxically, these fiscal austerity measures were unable to check the deteriorating trend in the budget deficit; rather, the loss of tax revenue resulting from the recession, rising debt service charges and the costs involved in the financial rescue resulted in a further deterioration in the fiscal position in 1999. A highly competitive exchange rate and the fall in interest rates that took place in 1999 helped bring about a moderate recovery in production activity in 2000 . 
All in all, economic growth was slow by the historical standards of the country, and was much more unstable. Average growth rates have been greatly affected by the severity of the recent crisis, considering that up until 1997 they stood at moderate levels that were only slightly lower than those seen in the second half of the 1980s. By contrast, instability -both in growth and, to an even greater extent, in aggregate demand-was one of the most striking features of the decade as a whole, all the more so in a country whose tradition of gradualism and anticyclical economic management had given it the reputation of having the most subdued economic cycles of any country in Latin America. Other notable features were the high current account deficit that persisted throughout most of the decade, associated in part with the rising trend of the currency, and the structural deterioration in the public finances.

In terms of the production structure, the pattern of economic growth was characterized by a rapid decline in the share of production accounted for by the agricultural and industrial sectors (table 2). This development has been manifest since the years of strong growth, showing that the rapid economic expansion of that time was dependent on the services and construction sectors, i.e., on non-tradable activities associated with internal demand. In fact, some agricultural activities, particularly crops with a short cycle (cereals and oil crops) went through a severe crisis in the early years of the 1990s. This high degree of dependence on domestic demand during the years of growth was also reflected in a slowdown in the rising trend that had been seen in the export coefficient from the mid-1980s to 1991 (table 1).

The crisis in certain activities that had experienced a strong upturn in the first half of the decade (construction and, latterly, financial services), together with the decline of manufacturing industry, which was particularly marked during the recent crisis, were the main changes seen in the production structure during the second half of the decade. Mining and a few services (transport and government services until the fiscal adjustment programmes began) were the only sources of growth, and weak ones at that, during this period.

TABLE 2

Colombia: Sectoral composition of GDP and employment

(Percentages)

\begin{tabular}{|c|c|c|c|c|c|c|c|c|}
\hline \multirow[b]{2}{*}{ Economic sector } & \multicolumn{5}{|c|}{ GDP (1975 prices) } & \multicolumn{3}{|c|}{ Employment } \\
\hline & 1985 & 1991 & 1995 & 1997 & 1999 & 1991 & 1995 & 1997 \\
\hline Agriculture & 21.9 & 21.8 & 19.3 & 18.8 & 19.9 & 26.7 & 22.2 & 22.9 \\
\hline Mining & 2.3 & 4.6 & 4.3 & 4.7 & 5.7 & 1.2 & 0.8 & 0.7 \\
\hline Manufacturing & 21.2 & 21.4 & 19.0 & 18.6 & 16.9 & 15.0 & 15.7 & 13.2 \\
\hline Electricity, gas and water & 1.0 & 1.1 & 1.1 & 1.1 & 1.2 & 0.6 & 0.5 & 0.9 \\
\hline Construction & 4.4 & 3.0 & 3.7 & 3.7 & 2.6 & 4.5 & 6.1 & 5.3 \\
\hline Trade & 12.1 & 11.5 & 11.9 & 12.0 & 11.5 & 20.7 & 21.7 & 21.9 \\
\hline Transport & 9.4 & 8.6 & 8.7 & 9.4 & 9.9 & 5.0 & 5.5 & 5.5 \\
\hline Financial services & 14.2 & 14.6 & 16.3 & 17.3 & 16.5 & 3.6 & 4.6 & 5.0 \\
\hline Other services & 13.2 & 13.2 & 12.9 & 14.5 & 16.1 & 22.6 & 22.8 & 24.7 \\
\hline Total & 100.0 & 100.0 & 100.0 & 100.0 & 100.0 & 100.0 & 100.0 & 100.0 \\
\hline Tradables & 45.4 & 47.8 & 42.6 & 42.1 & 42.5 & 43.0 & 38.7 & 36.8 \\
\hline Urban & & & & & & 14.2 & 14.1 & 12.5 \\
\hline Rural & & & & & & 28.8 & 24.7 & 24.3 \\
\hline Non-tradables & 54.3 & 52.0 & 54.7 & 57.9 & 57.6 & 57.0 & 61.3 & 63.2 \\
\hline Urban & & & & & & 43.9 & 47.0 & 49.4 \\
\hline Rural & & & & & & 13.1 & 14.3 & 13.8 \\
\hline
\end{tabular}

Source: DANE, National Household Survey and National Accounts. 


\section{IV}

\section{The labour market}

\section{General trends}

Figure 1 shows how the main labour market indicators have evolved in the seven biggest cities of Colombia since 1976, and compares them with the national indicators, which have been available only since $1991 .{ }^{4} \mathrm{It}$ shows that the 1980s were a period of rapid growth in urban labour force participation, mainly because of the speed with which women were entering the workforce, which in turn was due to the decline in fertility. Sluggish economic growth in the first half of that decade meant that job creation in the seven biggest cities was slow. This dynamic, in conjunction with the rise in participation referred to, led to a substantial increase in the unemployment rate, which peaked in 1986. Since then the labour market has changed dramatically. As the economy started to recover its dynamism, employment began to grow strongly, and this helped to bring down unemployment levels.

These trends in the urban labour market continued until 1992. Since then, and coinciding with the adoption of structural reforms, the tendency has changed again. After peaking in 1993, and despite continued strong growth in aggregate demand and rapid economic expansion, the rate of job creation in the seven biggest cities and in the urban sector as a whole began to decline. At the same time, the upward trend in the participation rate was checked, which meant that for some years the reduced dynamism of employment did not affect the unemployment rate. This rate, in fact, averaged $8.7 \%$ in the cities in 1993-1995, the lowest since the early 1980s. The trends seen in the rural labour market, by contrast, were negative during those years, owing to the severe crisis that affected the agricultural sector. In particular, employment fell sharply in rural areas between 1991 and 1993 and the unemployment rate tended to climb during the first half of the 1990s, although from levels much lower than those seen in urban areas. The overall effect of these opposing tendencies in urban and rural areas was a gently falling

\footnotetext{
${ }^{4}$ For previous years there are only two national surveys in existence, that of 1978 and that of 1988. The latter is not strictly comparable with the others as its figures for urban areas cover only the seven biggest cities.
}

FIGURE 1

Colombia: Labour market indicators, national and urban, 1976-1999

A. Unemployment rates

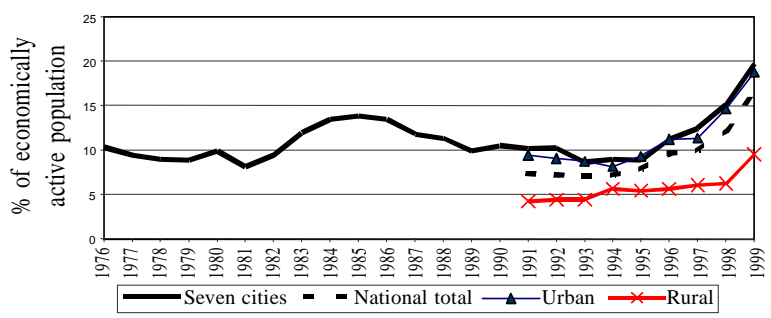

B. Employment rates

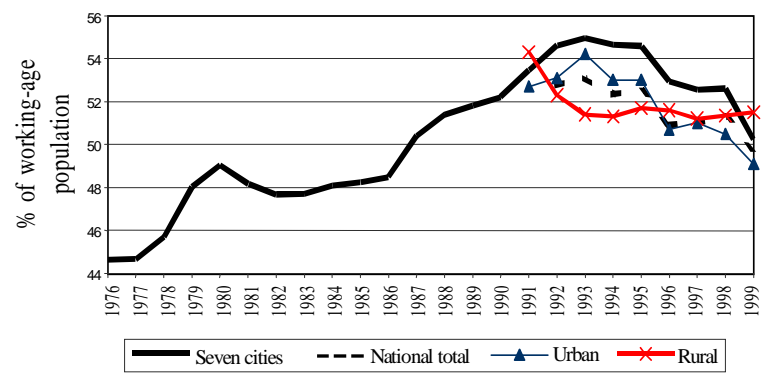

C. Participation rates

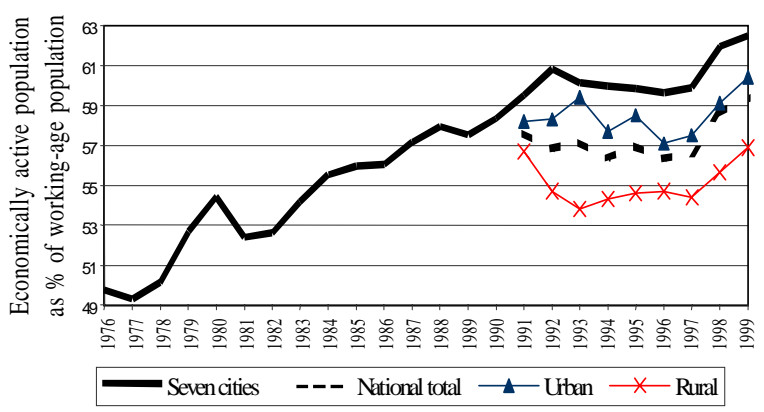

trend in the employment rate-once again, this was despite a strong economic upturn- which was offset by a similar movement in labour force participation, so that the national unemployment rate stayed close to $7 \%$.

In the second half of the decade there was a marked deterioration in the urban labour market, owing to the sharp fall in employment rates and the newly rising 
trend in participation rates. This new dynamic manifested itself, from 1996 onward, in the form of a rapid increase in the unemployment rate, so that by 1999 this stood at the highest level ever seen in the country. Although, as we shall see later, the lack of dynamism in employment cannot be attributed exclusively to internal demand, there can be no doubt whatsoever that in the most recent years this variable has played a decisive role. In particular, the biggest falls in the employment rate have coincided with periods of slowdown and recession (1996 and 1999), and in general there has been a clear association since 1996 between the behaviour of employment in the biggest cities and quarterly GDP changes (Colombia, DANE, 1999).

Overall, employment rates tended to fall throughout the decade, particularly in rural areas during the early part of it and in urban ones during the second half. In the country as a whole, the employment rate fell from $53 \%$ in the early years of the decade to just under 50\% in 1999. The renewed tendency for labour force participation to rise meant that this led to an explosion in unemployment. As we shall see, these tendencies were accompanied by major changes in the sectoral composition of employment.

Table 3 provides fuller details of movements in labour market indicators for 1991 and 1997, the two years selected for the purpose of analysing the effects of the reforms. As has already been noted, 1991 saw the completion of the trade reforms and inward FDI liberalization and the issuing of the new political charter. In 1997, the effects of the reforms can be appreciated, but the consequences of the severe crisis affecting the Colombian economy in recent years can also be identified.

The indicators given in table 3 show that female participation rates are much lower than male ones. The labour force participation of the latest generations of women has increased in urban areas, however, owing to higher levels of education and lower fertility rates. During the period under analysis, it transpires that male participation fell in urban and rural areas and female participation fell in rural areas (Henao and Parra, 1998; Farné, Vivas and Núñez, 1998 and Ribero and García, 1996).

Participation and employment rates rise as educational levels increase, regardless of age group, gender or geographical area. Between 1991 and 1997, employment rates fell for all educational groups, with the exception of more highly educated women. Unemployment is higher for women in all educational groups and for people with 10 to 15 years of education. Between
1991 and 1997, unemployment rose for all educational categories, with the exception of more highly qualified people in rural areas, this exception being due, however, to workers in this category withdrawing from the labour market, as their employment rate fell substantially. Among those with 10 to 15 years of schooling, the rise in unemployment was slightly higher among men. As regards age, most of the population, in both urban and rural areas, is in the 25 to 50 cohort, and it is in this age group too that the highest rates of employment and participation are found. Conversely, unemployment rates tend to fall as age increases.

\section{Employment trends}

To achieve a more detailed analysis of the dynamic of the labour market in Colombia, an exercise was devised to break down changes in its structure resulting from shifts in the supply of and demand for labour. ${ }^{5}$ The results are collected in table 4. This establishes that supply-side changes, whether they are due to demographic factors or to changes in the total participation rate, have to match changes in the structure of the labour market brought about by demand factors, i.e., by changes in the employment and unemployment rates, as a proportion, in both cases, of the total population of the country.

Three basic conclusions can be drawn from these results. The first, relating to supply, is that the supply of labour grew moderately during the period analysed. In 1991-1995 the positive effect of the demographic component was largely offset by the decline in labour force participation. The demographic effect halted entirely in the middle of the decade, giving rise, in conjunction with the continuing decline in labour force participation, to a fall in the labour supply in 19951997. As we have seen, the downward trend in participation came to an end in 1998, which is outside the reference period for analysing the effects of the reforms.

The second conclusion relates to the demand for labour: taking the period as a whole, the job creation capacity of the economy was very low. The inadequacy of the results achieved in this area were made manifest by a fall in the employment rate equivalent to 2.2 per-

\footnotetext{
${ }^{5}$ This section and the following ones define the main labour market indicators in relation to the total population, and thus depart from the approach traditionally followed in the study of the labour market whereby these variables are defined in relation to the working-age or economically active population. The methodology used is set out in Taylor (1998).
} 
TABLE 3

\section{Colombia: Main labour market indicators by gender, years of education, age and area, 1991-1997 \\ (Percentages)}

By area and gender, 1991 and 1997

\begin{tabular}{lllrr}
\hline & & & 1991 & 1997 \\
\hline & \multirow{2}{*}{ National } & Men & 78.4 & 74.0 \\
$\mathrm{~T}$ & & Women & 37.9 & 38.3 \\
$\mathrm{P}$ & \multirow{2}{*}{ Urban } & Men & 73.1 & 70.4 \\
$\mathrm{R}$ & & Women & 40.9 & 41.5 \\
& \multirow{2}{*}{ Rural } & Men & 84.4 & 82.6 \\
& & Women & 33.7 & 28.3 \\
\hline \multirow{2}{*}{ National } & Men & 4.3 & 6.8 \\
& & Women & 10.7 & 13.3 \\
$\mathrm{U}$ & \multirow{2}{*}{ Urban } & Men & 6.4 & 8.7 \\
$\mathrm{R}$ & & Women & 12.7 & 13.3 \\
& \multirow{2}{*}{ Rural } & Men & 2.2 & 2.9 \\
& & Women & 7.6 & 13.4 \\
\hline \multirow{2}{*}{ National } & Men & 75.1 & 69.0 \\
& & Women & 33.8 & 33.2 \\
$\mathrm{E}$ & \multirow{2}{*}{ Urban } & Men & 68.4 & 64.2 \\
$\mathrm{R}$ & \multirow{2}{*}{ Rural } & Women & 35.7 & 36.0 \\
& & Men & 82.6 & 80.1 \\
& & Women & 31.2 & 24.5 \\
\hline
\end{tabular}

\begin{tabular}{|c|c|c|c|c|}
\hline \multicolumn{5}{|c|}{ By area and age, 1991 and 1997} \\
\hline & & & 1991 & 1997 \\
\hline & \multirow[t]{3}{*}{ National } & 12 to 24 & 45.7 & 39.9 \\
\hline & & 25 to 50 & 66.7 & 66.8 \\
\hline & & Over 50 & 47.4 & 44.3 \\
\hline \multirow[t]{2}{*}{$\mathrm{T}$} & \multirow[t]{3}{*}{ Urban } & 12 to 24 & 41.9 & 37.5 \\
\hline & & 25 to 50 & 67.1 & 67.8 \\
\hline $\mathrm{P}$ & & Over 50 & 39.7 & 40.2 \\
\hline & \multirow[t]{3}{*}{ Rural } & 12 to 24 & 50.2 & 46.0 \\
\hline \multirow[t]{4}{*}{$\mathrm{R}$} & & 25 to 50 & 66.2 & 63.9 \\
\hline & & Over 50 & 55.5 & 54.1 \\
\hline & \multirow[t]{3}{*}{ National } & 12 to 24 & 14.1 & 19.0 \\
\hline & & 25 to 50 & 6.3 & 7.0 \\
\hline $\mathrm{U}$ & & Over 50 & 2.0 & 4.1 \\
\hline \multirow[t]{6}{*}{$\mathrm{R}$} & \multirow[t]{3}{*}{ Urban } & 12 to 24 & 20.1 & 22.9 \\
\hline & & 25 to 50 & 5.8 & 8.0 \\
\hline & & Over 50 & 3.6 & 5.1 \\
\hline & \multirow{3}{*}{ Rural } & 12 to 24 & 8.3 & 10.6 \\
\hline & & 25 to 50 & 2.2 & 4.1 \\
\hline & & Over 50 & 0.7 & 2.2 \\
\hline \multirow[b]{3}{*}{ E } & \multirow[t]{3}{*}{ National } & 12 to 24 & 39.3 & 32.2 \\
\hline & & 25 to 50 & 63.8 & 62.1 \\
\hline & & Over 50 & 46.4 & 42.5 \\
\hline \multirow[t]{6}{*}{$\mathrm{R}$} & \multirow[t]{3}{*}{ Urban } & 12 to 24 & 33.5 & 28.9 \\
\hline & & 25 to 50 & 63.2 & 62.4 \\
\hline & & Over 50 & 38.2 & 38.2 \\
\hline & \multirow[t]{3}{*}{ Rural } & 12 to 24 & 46.0 & 41.1 \\
\hline & & 25 to 50 & 64.8 & 61.3 \\
\hline & & Over 50 & 55.1 & 52.9 \\
\hline
\end{tabular}

By area and years of education, 1991 and 1997

\begin{tabular}{|c|c|c|c|c|}
\hline & & & 1991 & 1997 \\
\hline \multirow{9}{*}{$\begin{array}{l}\mathrm{T} \\
\mathrm{P} \\
\mathrm{R}\end{array}$} & \multirow[t]{3}{*}{ National } & 9 years or less & 54.1 & 50.2 \\
\hline & & 10 to 15 years & 64.9 & 65.7 \\
\hline & & More than 15 years & 88.4 & 86.9 \\
\hline & \multirow[t]{3}{*}{ Urban } & 9 years or less & 49.2 & 47.0 \\
\hline & & 10 to 15 years & 64.7 & 65.7 \\
\hline & & More than 15 years & 87.9 & 86.9 \\
\hline & \multirow[t]{3}{*}{ Rural } & 9 years or less & 58.5 & 56.2 \\
\hline & & 10 to 15 years & 65.5 & 66.4 \\
\hline & & More than 15 years & 96.1 & 88.4 \\
\hline \multirow[b]{3}{*}{$\mathrm{U}$} & \multirow[t]{2}{*}{ National } & 9 years or less & 5.3 & 8.0 \\
\hline & & 10 to 15 years & 11.7 & 13.3 \\
\hline & & More than 15 years & 4.0 & 5.2 \\
\hline \multirow[t]{6}{*}{$\mathrm{R}$} & \multirow[t]{3}{*}{ Urban } & 9 years or less & 8.4 & 10.0 \\
\hline & & 10 to 15 years & 11.5 & 13.3 \\
\hline & & More than 15 years & 4.0 & 5.3 \\
\hline & \multirow[t]{3}{*}{ Rural } & 9 years or less & 3.0 & 4.8 \\
\hline & & 10 to 15 years & 12.2 & 13.9 \\
\hline & & More than 15 years & 4.3 & 2.0 \\
\hline \multirow{9}{*}{$\begin{array}{l}\mathrm{E} \\
\mathrm{R}\end{array}$} & \multirow[t]{3}{*}{ National } & 9 years or less & 51.2 & 46.2 \\
\hline & & 10 to 15 years & 57.3 & 57.0 \\
\hline & & More than 15 years & 84.9 & 82.3 \\
\hline & \multirow[t]{3}{*}{ Urban } & 9 years or less & 45.1 & 42.3 \\
\hline & & 10 to 15 years & 57.2 & 57.0 \\
\hline & & More than 15 years & 84.4 & 82.2 \\
\hline & \multirow[t]{3}{*}{ Rural } & 9 years or less & 56.7 & 53.6 \\
\hline & & 10 to 15 years & 57.6 & 57.2 \\
\hline & & More than 15 years & 92.0 & 86.6 \\
\hline
\end{tabular}

By years of education and gender, 1991 and 1997

\begin{tabular}{|c|c|c|c|c|}
\hline & & & 1991 & 1997 \\
\hline \multirow{6}{*}{$\begin{array}{l}\mathrm{T} \\
\mathrm{P} \\
\mathrm{R}\end{array}$} & \multirow{2}{*}{9 years or less } & Men & 77.6 & 71.7 \\
\hline & & Women & 32.7 & 30.4 \\
\hline & \multirow[t]{2}{*}{10 to 15 years } & Men & 78.4 & 77.7 \\
\hline & & Women & 53.6 & 55.7 \\
\hline & \multirow[t]{2}{*}{ More than 15 years } & Men & 93.0 & 90.0 \\
\hline & & Women & 81.8 & 83.0 \\
\hline \multirow{6}{*}{$\begin{array}{l}\mathrm{U} \\
\mathrm{R}\end{array}$} & \multirow[t]{2}{*}{9 years or less } & Men & 3.5 & 6.0 \\
\hline & & Women & 9.2 & 12.3 \\
\hline & \multirow[t]{2}{*}{10 to 15 years } & Men & 72.1 & 69.9 \\
\hline & & Women & 45.0 & 46.2 \\
\hline & \multirow[t]{2}{*}{ More than 15 years } & Men & 90.1 & 86.1 \\
\hline & & Women & 77.4 & 77.6 \\
\hline & \multirow[t]{2}{*}{9 years or less } & Men & 74.8 & 67.4 \\
\hline & & Women & 29.7 & 26.7 \\
\hline E & \multirow{2}{*}{10 to 15 years } & Men & 8.0 & 10.1 \\
\hline $\mathrm{R}$ & & Women & 16.0 & 17.1 \\
\hline & \multirow[t]{2}{*}{ More than 15 years } & Men & 3.2 & 4.3 \\
\hline & & Women & 5.4 & 6.5 \\
\hline
\end{tabular}

Source: Calculated by the author on the basis of National Household Surveys.

TPR : Total participation rate

UR : Unemployment rate

ER : Employment rate 
TABLE 4

Colombia: Breakdown of overall changes in the labour market

(Percentage point changes in rates calculated

in relation to the total population)

\begin{tabular}{lccc}
\hline & $1991-1995$ & $1995-1997$ & $1991-1997$ \\
\hline \multicolumn{4}{c}{ Changes in labour supply } \\
Total $^{a}$ & 1.2 & -0.6 & 0.5 \\
Demographic $^{4}$ & 2.2 & -0.1 & 2.2 \\
Participation & -1.0 & -0.6 & -1.6 \\
\multicolumn{4}{c}{ Absorption by labour demand } \\
Employment $^{a}$ & 0.7 & -2.9 & -2.2 \\
Tradables & -3.9 & -3.0 & -7.0 \\
Non-tradables & 4.7 & 0.1 & 4.8 \\
Unemployment $^{4}$ & 0.5 & 2.1 & 2.6 \\
\hline
\end{tabular}

Source: Calculated by the author on the basis of National Household Surveys.

${ }^{a}$ The breakdown excludes the combined effect of changes in each of the components.

centage points of the entire population between 1991 and 1997, mainly owing to the sharp relative decline in job creation in sectors producing internationally tradable goods. The loss of employment in tradable sectors was a feature of the entire decade, and its severity means it must be associated with the effects of the structural reforms. Job creation in sectors producing non-tradable goods and services offset this during the upturn, but ceased to do so during the following years of slowing economic growth, which meant that the fall in employment in tradable sectors was fully reflected in the employment rate.

Lastly, the favourable combination of participation and employment trends in non-tradable sectors was neutral in its effect on unemployment up until 1995, after which the situation changed markedly, with unemployment rising by the equivalent of 2.1 percentage points of the total population between 1995 and 1997. As we have seen, the severe recession that followed and the renewal of the upward trend in labour force participation would cause the unemployment rate to explode over the following years.

Analysis of employment trends can be carried out at a level of one digit of the economic activity classification, and changes in the employment rate can be broken down into weighted changes in the difference between per capita output growth and changes in the labour productivity of each sector.

The results of this breakdown are given in table 5 . This shows that the general decline of employment in
TABLE 5

Colombia: Sectoral breakdown of labour productivity, output per capita and employment changes ${ }^{\mathrm{a}}$

(Percentages)

\begin{tabular}{lccr}
\hline & $1991-1995$ & $1995-1997$ & $1991-1997$ \\
& \multicolumn{2}{c}{ Growth in labour productivity } \\
Agriculture & 18.7 & -4.1 & 13.8 \\
Mining & 65.6 & 22.7 & 103.2 \\
Industry & -2.8 & 18.4 & 15.2 \\
Electricity, gas and water & 34.1 & -38.6 & -17.6 \\
Construction & 7.2 & 14.1 & 22.3 \\
Trade & 13.2 & 1.1 & 14.5 \\
Transport & 2.5 & 10.6 & 13.3 \\
Financial services & -3.0 & 0.1 & -2.9 \\
Other services & 11.7 & 4.4 & 16.6 \\
Total & 10.4 & 4.2 & 15.0 \\
Tradables & 12.0 & 5.6 & 18.3 \\
Non-tradables & 10.8 & 4.0 & 15.2
\end{tabular}

Per capita output growth

\begin{tabular}{lrrr} 
Agriculture & -0.7 & -3.9 & -4.6 \\
Mining & 9.0 & 8.5 & 18.3 \\
Industry & 2.7 & -3.7 & -1.1 \\
Electricity, gas and water & 11.7 & 2.5 & 14.6 \\
Construction & 46.9 & -4.1 & 40.8 \\
Trade & 19.8 & -0.9 & 18.7 \\
Transport & 13.6 & 6.1 & 20.4 \\
Financial services & 24.4 & 4.4 & 29.9 \\
Other services & 13.4 & 9.9 & 24.6 \\
Total & 11.2 & 1.2 & 12.5 \\
Tradables & 1.7 & -2.6 & -0.9 \\
Non-tradables & 19.8 & 4.2 & 24.8 \\
& & & \\
& & & \\
Agriculture & -4.4 & 0.0 & -4.3 \\
Mining & -0.4 & -0.1 & -0.5 \\
Industry & 0.8 & -2.9 & -2.1 \\
Electricity, gas and water & -0.1 & 0.3 & 0.2 \\
Construction & 1.7 & -1.0 & 0.7 \\
Trade & 1.2 & -0.4 & 0.8 \\
Transport & 0.5 & -0.2 & 0.3 \\
Financial services & 1.0 & 0.2 & 1.2 \\
Other services & 0.3 & 1.2 & 1.5 \\
Total & 0.7 & -2.9 & -2.2 \\
Tradables & -3.9 & -3.0 & -7.0 \\
Non-tradables & 4.7 & 0.1 & 4.8 \\
\hline
\end{tabular}

Source: Calculated by the author on the basis of National Household Surveys.

a The totals for the three breakdowns do not exactly match because the separate calculations exclude the combined effect of changes in each of the two components.

agriculture and industry was associated with a sharp fall in output per inhabitant combined with significant increases in labour productivity. As a result of this, between 1991 and 1997 the employment rate in trad-

THE LABOUR MARKET AND INCOME DISTRIBUTION IN COLOMBIA IN THE 1990S • JOSE ANTONIO OCAMPO, FABIO SANCHEZ 
able sectors fell by an amount equivalent to seven percentage points of the entire population. By contrast, sectors associated with non-tradable activities, chiefly services, saw a sustained increase in output per inhabitant, especially during the economic upturn. During those years, per capita output growth exceeded labour productivity growth. This meant that dynamic job creation could take place in these sectors, but this process was interrupted and even reversed in a number of sectors during the following years. The combined effects of the slowdown in job creation in non-tradable sectors from 1996 onward -associated with the slowdown in the economy- and the long-term decline of employment in tradable activities, therefore, account for the sharp fall in the total employment rate of the economy.

These general tendencies at the sectoral level have some peculiarities. On the one hand, the extent of the decline in agricultural sector employment between 1991 and 1995 is striking, particularly in rural areas, where the share of agricultural employment fell by more than four percentage points during those years (table 2). Between 1995 and 1997, by contrast, the fall in employment in tradable sectors was accounted for essentially by the industrial sector, although on this occasion it was associated with a worsening employment situation in urban areas, something that reflected both the effects of the structural adjustment and the slowdown in economic activity.

In conjunction, these tendencies brought about a rapid increase in the share of total employment accounted for by the non-tradable sectors, which rose from $57.0 \%$ in 1991 to $63.2 \%$ in 1997 (table 2). The procyclical behaviour of employment was particularly striking in the construction sector. This sector grew strongly between 1991 and 1995, but this period was followed by a recession whose effects on job creation are plain to see: the share of the construction sector in total employment rose from $4.5 \%$ in 1991 to $6.1 \%$ in 1995 and then fell again to 5.3\% in 1997.

The above analysis can be extended to take in the dynamic of job creation in each sector in relation to the educational level of workers, their occupational position and their sex. When movements in employment rates are compared by production sector and by level of schooling, two clearly defined patterns emerge (table 6). On the one hand, the employment rate for workers with less schooling fell throughout the decade, and this decline was far sharper in tradable sectors. On the other hand, most skilled jobs were created in the non-tradable sectors, especially financial services and other services, while in tradable sectors the situation as regards jobs requiring higher levels of education was one of stagnation.

In relation to the first point, it is important to note that between 1991 and 1995 the fall in the employment rate for less highly qualified workers, meaning those with some primary education ( $0-5$ years) or incomplete secondary education (6-10 years), was accounted for mainly by the agricultural sector. By contrast, between 1995 and 1997 the fall in the employment rate among these workers was particularly sharp in the industrial sector. In the case of the non-tradable sectors, job creation for less highly qualified workers behaves in a way that is clearly cyclical and is closely linked to the dynamic of the construction industry. During the expansion phase, in fact, this sector was the most dynamic source of new jobs for workers with a low level of education; conversely, during the adjustment phase it was this sector, after industry, that contributed most to the decline in the employment rate among these workers. What this dynamic suggests, then, is that in non-tradable sectors the creation of low-skilled jobs has been associated with the particular economic cycle of each sector. The ability of sectors producing tradable goods to create employment for workers with a low level of education, by contrast, has been in continuous decline.

The sectoral dynamic of the employment rate among highly qualified workers, those with incomplete (12-15 years) and complete (16 years and over) university or polytechnic education, has been subdued, with the exception of financial services and other services. New high-skilled jobs in the financial services and other services sectors alone account for two thirds of the increase in the employment rate among those with a higher level of education throughout the economy between 1991 and 1997. In the case of people with an intermediate level of education (complete secondary education, totalling 11 years of schooling), the trade sector, along with other services, has been the main source of new jobs, with the transport sector also making a major contribution.

Changes in the employment rate by occupational category and by sex, meanwhile, evince three important characteristics (table 7). The first is the markedly cyclical nature of waged job creation in the private sector. During the expansionary phase of the economy, this occupational category was the most dynamic of all in terms of job creation. Between 1995 and 1997, by contrast, it was here that the bulk of the contraction in the demand for labour occurred. The second is the dynamic role played by own-account employment over

THE LABOUR MARKET AND INCOME DISTRIBUTION IN COLOMBIA IN THE 1990S • JOSE ANTONIO OCAMPO, FABIO SANCHEZ 
TABLE 6

Colombia: Changes in the employment rate by educational level and branch of activity

(Percentages)

\begin{tabular}{|c|c|c|c|c|c|c|c|c|c|}
\hline \multirow{2}{*}{$\begin{array}{l}\text { Average years of education/ } \\
\text { Branch of activity }\end{array}$} & \multicolumn{3}{|c|}{$0-5$ years } & \multicolumn{3}{|c|}{$6-10$ years } & \multicolumn{3}{|c|}{11 years } \\
\hline & 1991-1995 & 1995-1997 & 1991-1997 & $1991-1995$ & 1995-1997 & 1991-1997 & 1991-1995 & 1995-1997 & 1991-1997 \\
\hline Agriculture & -3.3 & -0.2 & -3.5 & -0.6 & -0.1 & -0.7 & -0.2 & 0.2 & 0.0 \\
\hline Mining & -0.2 & -0.2 & -0.4 & 0.0 & -0.1 & -0.1 & 0.0 & 0.1 & 0.0 \\
\hline Industry & -0.1 & -1.1 & -1.2 & 0.1 & -1.3 & -1.2 & 0.9 & -0.6 & 0.3 \\
\hline Electricity, gas and water & 0.0 & 0.1 & 0.0 & 0.0 & 0.0 & 0.0 & 0.0 & 0.1 & 0.1 \\
\hline Construction & 0.8 & -0.5 & 0.3 & 0.6 & -0.6 & 0.0 & 0.2 & 0.0 & 0.2 \\
\hline Trade & 0.0 & -0.4 & -0.4 & 0.0 & -0.4 & -0.4 & 1.0 & 0.1 & 1.1 \\
\hline Transport & 0.1 & -0.4 & -0.3 & 0.2 & -0.2 & 0.0 & 0.3 & 0.2 & 0.5 \\
\hline Financial services & 0.1 & 0.0 & 0.2 & 0.2 & -0.1 & 0.0 & 0.3 & 0.0 & 0.3 \\
\hline Other services & -0.3 & 0.1 & -0.3 & -0.2 & -0.2 & -0.4 & 0.7 & 0.3 & 1.1 \\
\hline Total & -3.0 & -2.5 & -5.6 & 0.3 & -3.0 & -2.7 & 3.2 & 0.3 & 3.5 \\
\hline Tradables & -3.7 & -1.4 & -5.1 & -0.5 & -1.4 & -2.0 & 0.6 & -0.3 & 0.3 \\
\hline Non-tradables & 0.6 & -1.1 & -0.5 & 0.8 & -1.6 & -0.7 & 2.6 & 0.6 & 3.2 \\
\hline \multirow{2}{*}{$\begin{array}{l}\text { Average years of education/ } \\
\text { Branch of activity }\end{array}$} & \multicolumn{3}{|c|}{$12-15$ years } & \multicolumn{3}{|c|}{16 years and more } & \multicolumn{3}{|c|}{ Total } \\
\hline & $1991-1995$ & 1995-1997 & $1991-1997$ & $1991-1995$ & 1995-1997 & 1991-1997 & 1991-1995 & 1995-1997 & 1991-1997 \\
\hline Agriculture & -0.1 & 0.0 & 0.0 & -0.1 & 0.1 & 0.0 & -4.4 & 0.0 & -4.3 \\
\hline Mining & 0.0 & 0.0 & 0.0 & -0.1 & 0.1 & 0.0 & -0.4 & -0.1 & -0.5 \\
\hline Industry & 0.0 & -0.1 & -0.1 & 0.0 & 0.1 & 0.1 & 0.8 & -2.9 & -2.1 \\
\hline Electricity, gas and water & 0.0 & 0.0 & 0.0 & 0.0 & 0.1 & 0.1 & -0.1 & 0.3 & 0.2 \\
\hline Construction & 0.0 & 0.0 & 0.1 & 0.1 & 0.1 & 0.1 & 1.7 & -1.0 & 0.7 \\
\hline Trade & 0.1 & 0.0 & 0.2 & 0.0 & 0.3 & 0.3 & 1.2 & -0.4 & 0.8 \\
\hline Transport & 0.0 & 0.1 & 0.0 & 0.0 & 0.1 & 0.1 & 0.5 & -0.2 & 0.3 \\
\hline Financial services & 0.2 & 0.0 & 0.2 & 0.2 & 0.3 & 0.5 & 1.0 & 0.2 & 1.2 \\
\hline Other services & -0.2 & 0.5 & 0.3 & 0.3 & 0.6 & 0.8 & 0.3 & 1.2 & 1.5 \\
\hline Total & 0.0 & 0.6 & 0.7 & 0.2 & 1.7 & 2.0 & 0.7 & -2.9 & -2.2 \\
\hline Tradables & -0.1 & -0.1 & -0.2 & -0.3 & 0.3 & 0.0 & -3.9 & -3.0 & -7.0 \\
\hline Non-tradables & 0.1 & 0.7 & 0.8 & 0.5 & 1.5 & 2.0 & 4.7 & 0.1 & 4.8 \\
\hline
\end{tabular}

Source: Calculated by the author on the basis of National Household Surveys.

a Contribution of each sector to employment growth relative to the total population. The totals of the three breakdowns do not exactly match because the separate calculations exclude the combined effect of changes in each of the two components.

TABLE 7

Colombia: Dynamic of employment by occupational category and gender (Percentages)

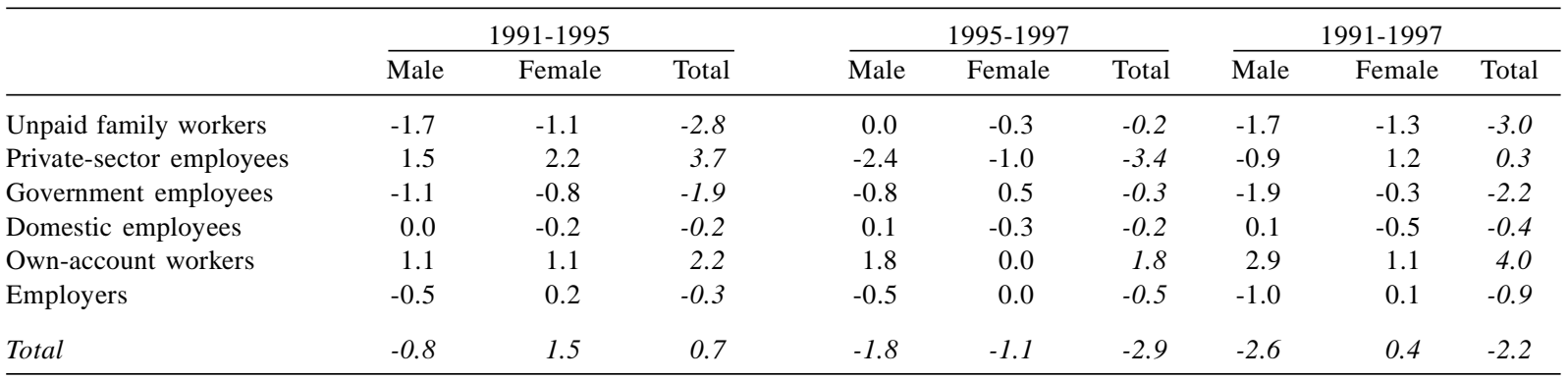

Source: Calculated by the author on the basis of National Household Surveys.

a Contribution of each sector to employment growth relative to the total population. The totals of the three breakdowns do not exactly match because the separate calculations exclude the combined effect of changes in each of the two components. 
the course of the decade. The conjunction of these two factors during the years of slowing growth undoubtedly points to a growing trend towards informal working. Lastly, female employment rates increased in relative terms; in recent years, however, this tendency has slowed considerably.

Overall, the results suggest that tradable activities are largely responsible for the sluggishness of employment. Meanwhile, it was only during the years of strong growth that non-tradable activities were able to absorb the mass of people displaced from the tradable sectors or seeking work for the first time. The results also suggest that the change in the dynamic of employment by qualification level is closely linked to changes in the sectoral structure of production: the decline of tradable sectors (particularly in agriculture and industry) has resulted in a continuous reduction in the demand for workers with a low level of education, while strong growth in certain non-tradable sectors (financial services and other services) has chiefly generated demand for qualified labour.

\section{Changes in the dynamic of productivity}

To analyse the extent to which rising labour productivity in the economy as a whole has been the result, on the one hand, of productivity improvements in specific production sectors and, on the other, of changes in the composition of production or employment, table 8 shows the results of three different exercises that involved breaking down changes in overall labour productivity. The first (A) breaks down these changes into the sectoral sum of the difference between changes in output and employment growth, each weighted by its share in total output and employment. The second and third (B and C) break down total labour productivity growth into a weighted average for productivity changes in each sector plus a term that reallocates output or employment between sectors, respectively.

The results of the first breakdown suggest that the increase in the productivity of the economy came about through a combination of several factors. The contribution of tradable sectors to total productivity growth in the economy was substantial, but it was associated, in agriculture and industry, with a combination of low output growth and rapidly falling employment in these sectors. This is particularly true in the agricultural sector during the period 1991-1995 and in industry during 1995-1997, i.e., during the years in which these sectors were undergoing the severest adjustment. In the case of mining, by contrast, the strong contribution of this sector to overall growth in the productivity of the economy was made in a context of strongly and steadily rising output. Something similar happened in the nontradable sectors during the period of strong growth, which continued, albeit at a slowing rate, until 1997.

The second and third breakdowns are alternative, although equivalent, exercises. Their most striking aspect is the fact that the productivity associated with the dynamic of each of the sectors was the determining factor in the rise of total productivity in the economy, while the effect of reallocating output or labour between sectors was very small. The relative growth of the financial sector, and the redeployment of labour to this sector, was a source of rising productivity, but was offset by similar processes of relative growth in other nontradable sectors, particularly trade and other services.

\section{The dynamic of wage incomes}

Earnings showed a moderate downward trend throughout the 1980s (figures 2 and 3). By contrast, real earnings for the different branches of economic activity and educational levels increased steadily from 1991 onward. There was a general rise in wages in all branches of economic activity, particularly government and financial services. In the construction sector incomes also increased greatly at the beginning of the decade, but this rise was quickly cut short when the upturn ended.

The dynamic of earnings by educational level provides another perspective (figure 3). Although earnings increased for all educational levels in the early 1990s, this tendency was not sustained. From 1994 onward, in fact, earnings began to stagnate at all educational levels, except for people with university education, and from 1996 onward wage incomes began to fall by stages, the exception being the earnings of workers with complete or incomplete university or polytechnic education. The wage dynamic experienced from 1996 onward is evidence that the earnings of workers with a lower level of education are more closely linked to the economic cycle than those of more highly educated groups of workers. Again, the sustained increase in the remuneration of those with a higher level of education -particularly workers who have completed university studiesby comparison with all other educational levels shows that, as a result of the shift in sectoral composition towards tradable sectors and of the technological changes spurred by the reform process, relative demand for well-qualified labour has increased and, perhaps, that the supply of workers with a high level of education

THE LABOUR MARKET AND INCOME DISTRIBUTION IN COLOMBIA IN THE 1990S • JOSE ANTONIO OCAMPO, FABIO SANCHEZ 
TABLE 8

Colombia: Breakdown of average annual labour productivity growth ${ }^{\mathrm{a}}$

(Percentages)

\begin{tabular}{|c|c|c|c|c|c|c|c|c|c|}
\hline & 1991-1995 & $1995-1997$ & 1991-1997 & 1991-1995 & $1995-1997$ & 1991-1997 & \multirow[t]{2}{*}{ 1991-1995 } & $1995-1997$ & 1991-1997 \\
\hline A. & \multicolumn{3}{|c|}{$\begin{array}{l}\text { Change in output weighted } \\
\text { by sectoral output share }\end{array}$} & \multicolumn{3}{|c|}{$\begin{array}{l}\text { Change in employment weighted } \\
\text { by sectoral employment share }\end{array}$} & & \multicolumn{2}{|l|}{ Total } \\
\hline Agriculture & 0.4 & 0.0 & 0.2 & -0.7 & 0.4 & -0.3 & 1.0 & -0.5 & 0.5 \\
\hline Mining & 0.2 & 0.2 & 0.2 & -0.1 & 0.0 & -0.1 & 0.3 & 0.3 & 0.3 \\
\hline Industry & 0.5 & 0.0 & 0.3 & 0.5 & -1.2 & -0.1 & 0.0 & 1.2 & 0.5 \\
\hline Electricity, gas and water & 0.1 & 0.0 & 0.1 & 0.0 & 0.2 & 0.1 & 0.1 & -0.2 & 0.0 \\
\hline Construction & 0.4 & 0.0 & 0.3 & 0.5 & -0.4 & 0.2 & -0.1 & 0.4 & 0.1 \\
\hline Trade & 0.8 & 0.2 & 0.6 & 0.7 & 0.2 & 0.5 & 0.1 & 0.0 & 0.1 \\
\hline Transport & 0.5 & 0.4 & 0.5 & 0.2 & 0.0 & 0.2 & 0.2 & 0.5 & 0.3 \\
\hline Financial services & 1.2 & 0.7 & 1.1 & 0.3 & 0.2 & 0.3 & 0.9 & 0.5 & 0.8 \\
\hline Other services & 0.7 & 0.9 & 0.8 & 0.5 & 1.0 & 0.7 & 0.2 & -0.1 & 0.1 \\
\hline Total $^{b}$ & 4.5 & 2.4 & 3.8 & 1.9 & 0.3 & 1.4 & 2.7 & 2.1 & 2.6 \\
\hline Tradables & 1.1 & 0.2 & 0.8 & -0.3 & -0.9 & -0.5 & 1.3 & 1.1 & 1.3 \\
\hline Non-tradables & 3.5 & 2.2 & 3.1 & 2.2 & 1.1 & 1.9 & 1.4 & 1.0 & 1.4 \\
\hline B. & \multicolumn{3}{|c|}{ Productivity weighted by output } & \multicolumn{3}{|c|}{ Reallocation term } & \multicolumn{3}{|c|}{ Total labour productivity } \\
\hline Agriculture & 1.0 & -0.4 & 0.5 & -0.1 & 0.0 & 0.0 & 0.9 & -0.4 & 0.5 \\
\hline Mining & 0.7 & 0.4 & 0.8 & 0.1 & 0.2 & 0.2 & 0.9 & 0.7 & 0.9 \\
\hline Industry & -0.1 & 1.8 & 0.5 & 0.2 & 0.0 & 0.1 & 0.0 & 1.8 & 0.6 \\
\hline Electricity, gas and water & 0.1 & -0.2 & 0.0 & 0.0 & 0.0 & 0.0 & 0.1 & -0.2 & 0.0 \\
\hline Construction & 0.1 & 0.3 & 0.1 & -0.2 & 0.0 & -0.1 & -0.2 & 0.3 & 0.0 \\
\hline Trade & 0.4 & 0.1 & 0.3 & -0.7 & -0.1 & -0.5 & -0.3 & -0.1 & -0.2 \\
\hline Transport & 0.1 & 0.5 & 0.2 & 0.2 & 0.2 & 0.2 & 0.3 & 0.6 & 0.4 \\
\hline Financial services & -0.1 & 0.0 & -0.1 & 0.9 & 0.5 & 0.8 & 0.8 & 0.5 & 0.8 \\
\hline Other services & 0.4 & 0.3 & 0.4 & -0.5 & -0.7 & -0.6 & -0.1 & -0.4 & -0.3 \\
\hline Total $^{b}$ & 2.5 & 2.1 & 2.5 & 0.0 & 0.0 & 0.0 & 2.7 & 2.1 & 2.6 \\
\hline Tradables & 1.4 & 1.2 & 1.4 & 0.1 & 0.0 & 0.1 & 1.5 & 1.3 & 1.5 \\
\hline Non-tradables & 1.4 & 1.1 & 1.3 & -0.4 & -0.2 & -0.3 & 1.0 & 0.9 & 1.0 \\
\hline C. & \multicolumn{3}{|c|}{ Productivity weighted by employment } & \multicolumn{3}{|c|}{ Reallocation term } & \multicolumn{3}{|c|}{ Total labour productivity } \\
\hline Agriculture & 1.2 & -0.5 & 0.6 & 0.1 & 0.0 & 0.1 & 1.3 & -0.5 & 0.7 \\
\hline Mining & 0.2 & 0.1 & 0.2 & -0.2 & -0.2 & -0.2 & 0.0 & 0.0 & 0.0 \\
\hline Industry & -0.1 & 1.4 & 0.4 & 0.2 & -0.3 & 0.0 & 0.1 & 1.1 & 0.3 \\
\hline Electricity, gas and water & 0.1 & -0.1 & 0.0 & 0.0 & 0.2 & 0.0 & 0.0 & 0.1 & 0.0 \\
\hline Construction & 0.1 & 0.4 & 0.2 & -0.2 & 0.1 & -0.1 & -0.1 & 0.6 & 0.1 \\
\hline Trade & 0.7 & 0.1 & 0.5 & -0.3 & -0.1 & -0.2 & 0.4 & 0.0 & 0.3 \\
\hline Transport & 0.0 & 0.3 & 0.1 & 0.2 & 0.0 & 0.1 & 0.2 & 0.3 & 0.2 \\
\hline Financial services & 0.0 & 0.0 & 0.0 & 1.1 & 0.5 & 0.9 & 1.0 & 0.5 & 0.9 \\
\hline Other services & 0.7 & 0.5 & 0.6 & -0.2 & -0.4 & -0.3 & 0.4 & 0.1 & 0.3 \\
\hline Total $^{b}$ & 2.7 & 2.3 & 2.4 & 0.6 & -0.2 & 0.3 & 2.7 & 2.1 & 2.6 \\
\hline Tradables & 1.3 & 1.1 & 1.3 & 0.0 & -0.1 & -0.1 & 1.3 & 1.1 & 1.3 \\
\hline Non-tradables & 1.5 & 1.2 & 1.4 & -0.2 & -0.1 & -0.2 & 1.4 & 1.0 & 1.4 \\
\hline
\end{tabular}

Source: Calculated by the author on the basis of National Household Surveys.

a Contribution of each sector to employment growth relative to the total population.

b The totals of the three breakdowns do not exactly match because the separate calculations exclude the combined effect of changes in each of the two components. 

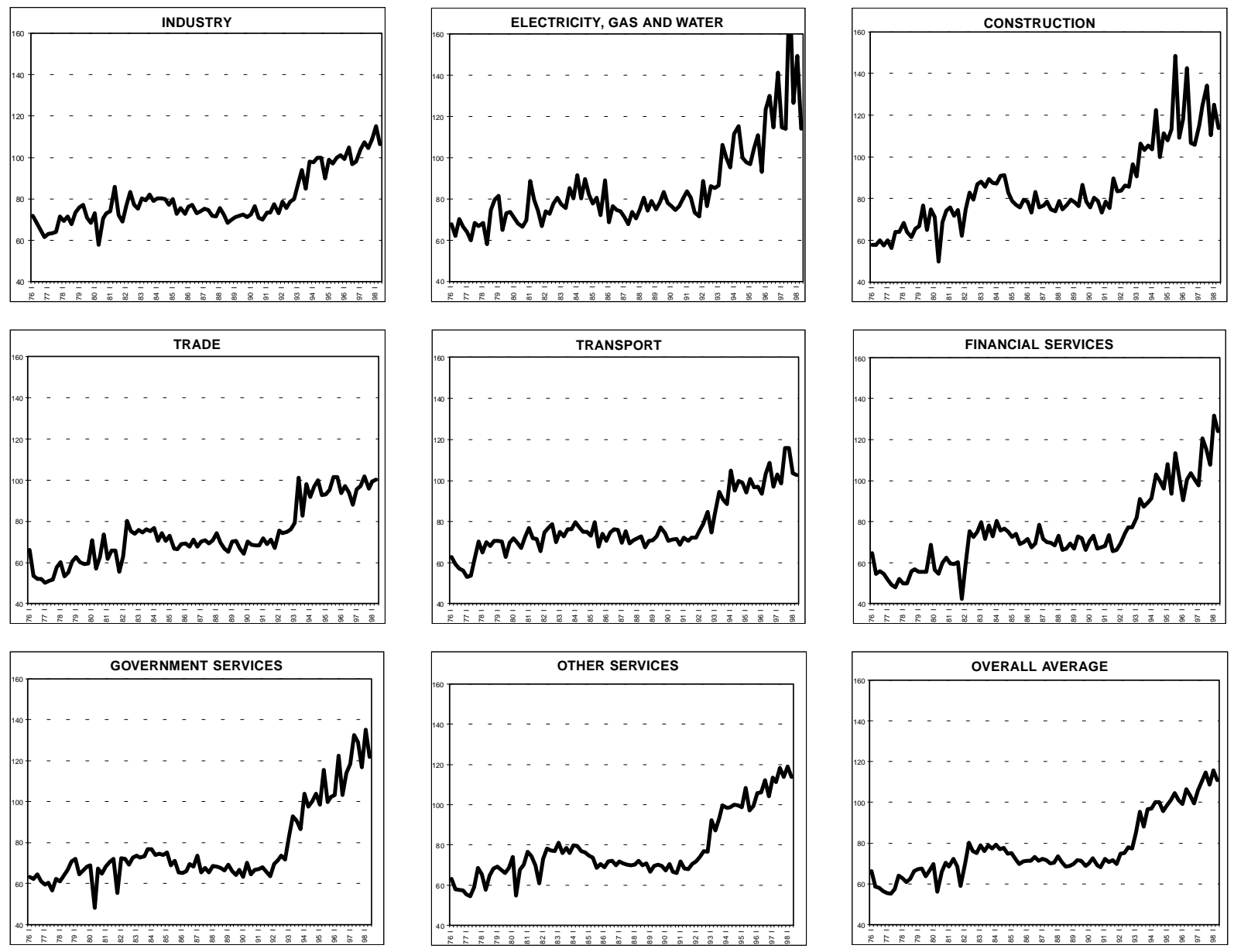

Source: National Household Survey.

has not kept pace with these changes in the composition of labour demand (table 9).

The dynamic of actual wages is in contrast with that of the minimum wage which, after falling $6 \%$ at the beginning of the decade (between 1985-1989 and 1991-1992) remained fairly stable. As a result of this, and of the increase in average wages, the proportion of the population below the minimum wage has fallen. In fact, ILO (1998) has estimated that the percentage of waged workers earning less than twice the legal minimum wage was just $63 \%$ in 1997 , as against $80 \%$ or so in 1990. 
A. Real urban earnings

(Index December 1994=100)
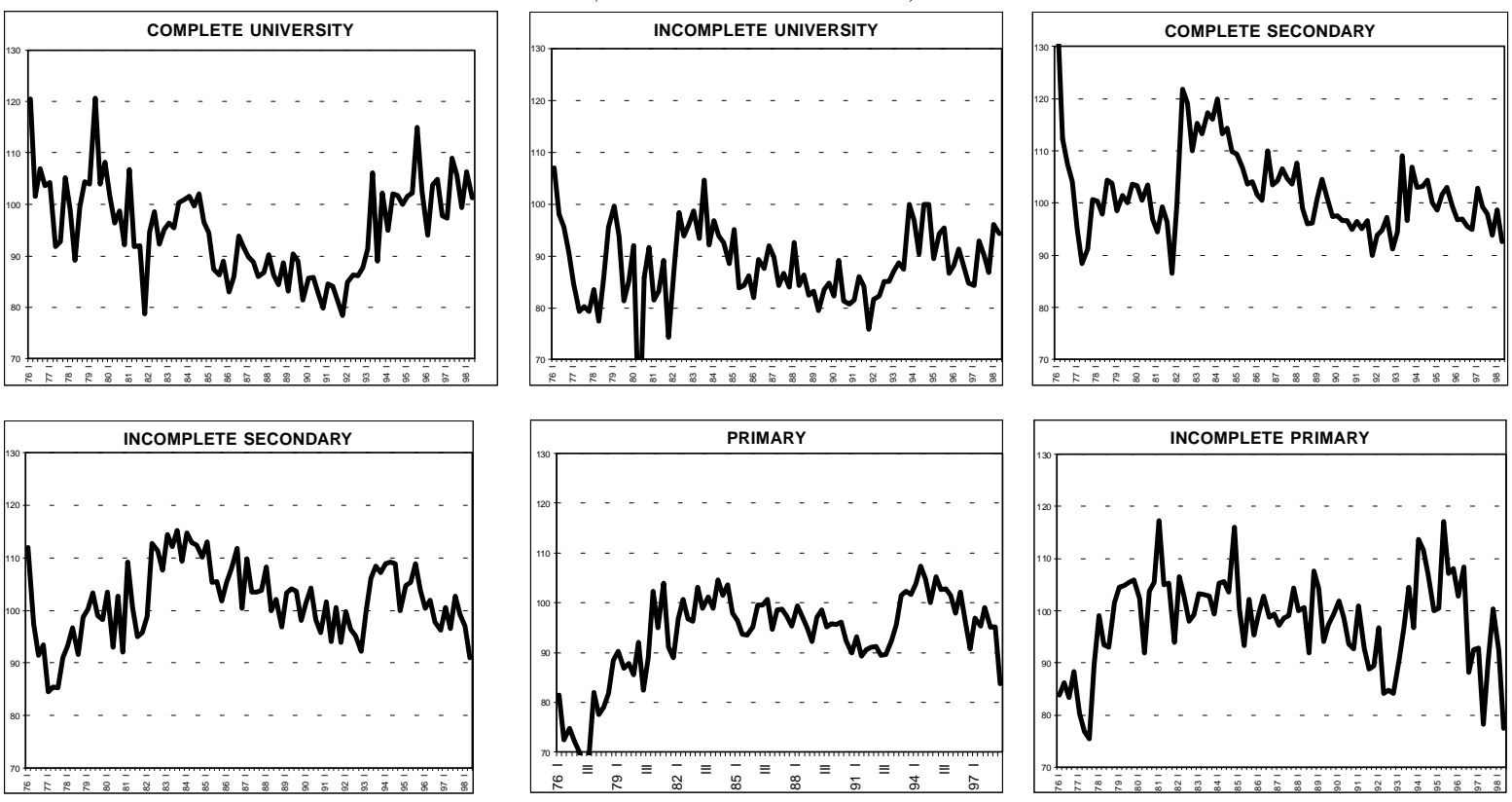

B. Relative urban earnings

(Index December 1994=100)
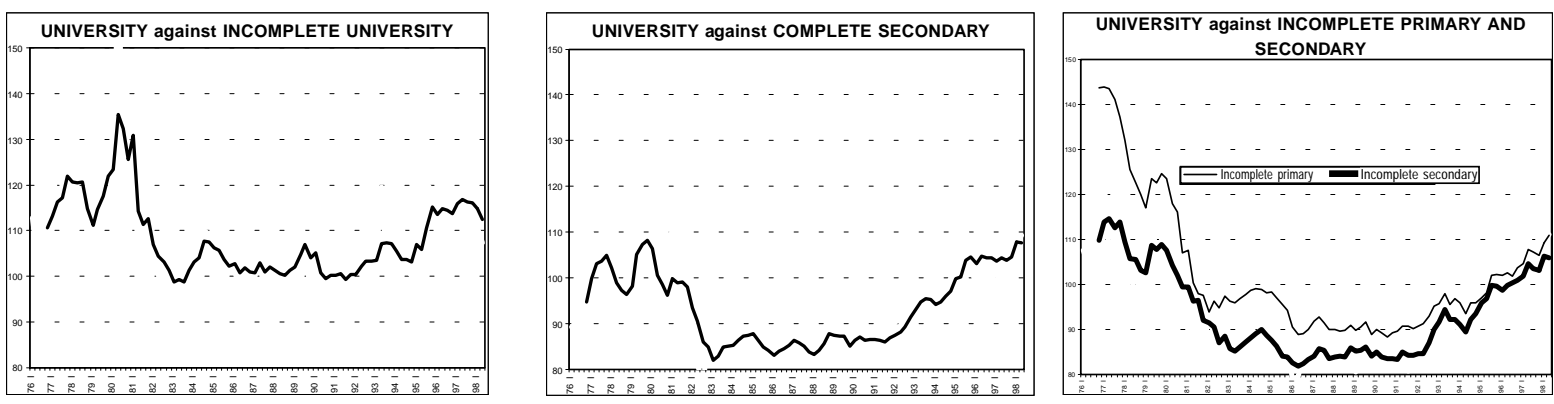

Source: National Household Survey.

TABLE 9

Colombia: Increases in earnings by educational level, 1993 and 1997

\begin{tabular}{|c|c|c|c|c|c|c|c|c|c|c|c|c|c|c|}
\hline & \multicolumn{2}{|c|}{ Quintile 1 } & \multicolumn{2}{|c|}{ Quintile 2} & \multicolumn{2}{|c|}{ Quintile 3} & \multicolumn{2}{|c|}{ Quintile 4} & \multicolumn{2}{|c|}{ Quintile 5} & \multicolumn{2}{|c|}{ Total } & \multicolumn{2}{|c|}{ Recalculated Gini } \\
\hline & 1993 & 1997 & 1993 & 1997 & 1993 & 1997 & 1993 & 1997 & 1993 & 1997 & 1993 & 1997 & 1993 & 1997 \\
\hline Education & 22.9 & 28.0 & 8.1 & 11.0 & 5.2 & 5.5 & 2.8 & 2.7 & 0.9 & 0.9 & 3.4 & 3.6 & 0.513 & 0.541 \\
\hline Primary & 16.8 & 19.9 & 4.4 & 6.6 & 2.1 & 2.4 & 0.7 & 0.7 & 0.1 & 0.1 & 1.6 & 1.7 & 0.520 & 0.548 \\
\hline Secondary & 5.6 & 7.0 & 3.1 & 3.5 & 2.1 & 1.8 & 1.1 & 0.7 & 0.2 & 0.1 & 1.2 & 1.0 & 0.528 & 0.558 \\
\hline University & 0.6 & 1.2 & 0.6 & 1.0 & 1.1 & 1.2 & 1.0 & 1.4 & 0.5 & 0.7 & 0.7 & 1.0 & 0.535 & 0.564 \\
\hline Health & 11.9 & 45.5 & 6.5 & 15.3 & 5.3 & 9.5 & 3.0 & 2.3 & 0.9 & -0.4 & 2.9 & 4.2 & 0.520 & 0.523 \\
\hline Subsidized system & 10.7 & 42.8 & 4.2 & 12.8 & 2.7 & 6.3 & 1.0 & 1.2 & 0.3 & 0.1 & 1.5 & 3.5 & 0.524 & 0.530 \\
\hline Contrib & 1.3 & 2.7 & 2.3 & 2.5 & 2.6 & 3.2 & 1.9 & 1.2 & 0.6 & -0.6 & 1.4 & 0.7 & 0.532 & 0.558 \\
\hline Public services & 5.8 & 13.3 & 4.3 & 5.4 & 3.6 & 3.6 & 2.4 & 1.9 & 1.1 & 0.6 & 2.2 & 2.1 & 0.528 & 0.553 \\
\hline Water & 1.6 & 4.6 & 1.2 & 1.8 & 1.0 & 1.3 & 0.6 & 0.7 & 0.3 & 0.2 & 0.6 & 0.8 & 0.533 & 0.561 \\
\hline Electricity & 4.2 & 8.7 & 3.1 & 3.5 & 2.6 & 2.3 & 1.8 & 1.2 & 0.9 & 0.4 & 1.6 & 1.3 & 0.530 & 0.557 \\
\hline Total & 40.7 & 86.8 & 18.9 & 31.7 & 14.1 & 18.6 & 8.2 & 6.9 & 2.9 & 1.1 & 8.5 & 9.9 & 0.492 & 0.491 \\
\hline Reference datum & & & & & & & \multicolumn{6}{|c|}{ Gini before subsidy: } & 0.535 & 0.565 \\
\hline
\end{tabular}

Source: Sánchez and Núñez (1999).

THE LABOUR MARKET AND INCOME DISTRIBUTION IN COLOMBIA IN THE 1990S • JOSE ANTONIO OCAMPO, FABIO SANCHEZ AND CAMILO ERNESTO TOVAR 
$\mathrm{V}$

\section{Effects of the labour market on income distribution}

\section{A brief review of the literature}

A number of recent studies have shown that the tendency for income distribution to improve in urban areas which began in the 1970s continued throughout much of the 1980s, but that this tendency was reversed in the late 1980s, to be followed by quite a marked deterioration in distribution in the 1990 s. $^{6}$ In rural areas, the opposite trends have been seen: a deterioration in income distribution between 1978 and 1988, followed by an improvement in the first half of the 1990s, which was only partially reversed in the second half. Although these opposing trends tended to offset one another in the early years of the 1990s, the adverse developments seen in urban areas ultimately prevailed, bringing about a deteriorating income distribution situation in the country as a whole (Colombia, DNP/UNDP, 1998; Leibovich and Núñez, 1999; Ocampo, Pérez, Tovar and Lasso, 1998; Sánchez and Núñez, 1999 and Vélez, Kugler and Bouillon, 1999). In fact, as table 10 shows, primary income distribution in the country as a whole deteriorated between 1991 and 1997 by just under two percentage points of the Gini coefficient, owing to an adverse movement of over four points in urban areas, which prevailed over the rise of around four points in rural areas. This development in primary income distribution nationally, however, was offset by the favourable distributive effect of increased public social spending and better targeting of this, which meant that it benefited poorer sectors more (Sánchez and Núñez, 1999); in other words, by improved secondary income distribution. The conclusion would seem to be that overall distribution (primary and secondary) did not show any clear tendency over the course of the decade.

In rural-urban terms, Ocampo, Pérez, Tovar and Lasso (1998) and Sánchez and Núñez (1999) show that in the 1990s massive income redistribution took place

\footnotetext{
${ }^{6} \mathrm{~A}$ common feature of recent studies is that they correct the results of household surveys to take account of non-disclosure problems relating to the highest incomes. The correction methods used combine with the problems traditionally encountered when household surveys are processed (the need to correct for unreported or under-reported income, consistency with national accounts, etc.) to produce discrepancies between the estimates of different authors.
}

between the city and the countryside, the biggest gainers being the highest-income sectors in urban areas and the biggest losers the highest-income sectors in rural areas. ${ }^{7}$ What the first study primarily shows is an increase in the relative earnings of the most highly qualified workers, while the second shows a kind of "levelling down" of rural incomes as a result of the crisis in commercial farming. In terms of gender, meanwhile, Vélez, Kugler and Bouillon (1999) show that among men the income gap fell between 1978 and 1988, but increased sharply between 1988 and 1995. By contrast, the tendency towards greater income concentration among women was a characteristic of the 1978-1995 period as a whole.

According to Ocampo, Pérez, Tovar and Lasso (1998), the favourable distribution tendencies that characterized urban areas in the 1980 s can be accounted for by a combination of more and better distributed education, the narrowing of the income gap by educational level, the good working opportunities available from the middle of the decade onwards and the lower economic dependence rate in households, facilitated by the demographic transition and the resulting increase in female workforce participation. Fewer working opportunities, growing differentials in earnings from work by educational level and relative growth in non-wage income, on the other hand, were the adverse factors that caused income distribution to worsen in the 1990s. These effects outweighed the impact of favourable tendencies, such as improvements in the quantity and distribution of education, changes in demographic patterns, rising female participation in the workforce and declining average household size, which still continued, albeit at a slower pace. In rural areas, according to this study, trade liberalization destroyed major sources of income, and this had particularly severe effects on big landowners and wage earners in commercial farming, two groups that are in the highest deciles of rural income distribution. The net effect, therefore, was a downward "levelling" of income, which led to better distribution of dwindling rural incomes.

\footnotetext{
${ }^{7}$ These studies disagree as to the amount of the losses suffered by other rural income recipients.
} 
The significant changes seen in the distribution trend for earnings in urban areas can also be expressed as the outcome of large changes in the profitability of education: a declining trend in the 1980s, followed by a substantial increase in the profitability of university education in the 1990s (Sánchez and Núñez, 1998). According to this study, these changes in relative wages are due to alterations not in the relative supply of labour but rather in the demand for it, and are related to technological change, the structure of sectoral production, relative factor productivity, the economic liberalization and economic adjustment process and changes in the prices of non-labour factors, in particular the relative price of capital.

The analysis carried out by Leibovich and Núñez (1999) for the rural sector shows, for the period 19881995, that income distribution improved for both wage earners and own-account workers of both sexes. This result was positively influenced by: changes in personal circumstances (education and household size in particular), in labour force participation and in the profitability of education. They also calculated the Gini and entropic measures which show that there is less inequity among wage earners than among own-account workers, whether male or female. Again, just as in the studies dealing with cities, the Gini is higher for women than for men.

Changes in distribution were heavily influenced by increases in the homogeneity or heterogeneity of incomes within groups with the same basic characteristics (in terms of age, gender, education, experience, family headship and residence, in particular). ${ }^{8}$ According to Vélez, Kugler and Bouillon (1999), increased income homogeneity in such groups accounts for a large part of the improvement in urban income distribution in the period 1978-1988, and increased heterogeneity for much of the reversal seen in the following period. For the recent period, Leibovich and Núñez (1999) find that increased income homogeneity among workers with similar occupational characteristics was one of the factors underlying the improvement in rural income distribution.

A number of studies, again, have tried to explore the effects of macroeconomic variables on income distribution. Bernal, Cárdenas, Sánchez and Núñez (1998) find that a relative increase in the size of the tradable sectors tends to reduce the Gini coefficient, while higher

${ }^{8}$ These effects are captured by residuals (unexplained effects) in income generation functions. inflation, a higher unemployment rate and real currency depreciation tend to raise it. Although the results of Ocampo, Pérez, Tovar and Lasso (1998) do not bear out some of these results (particularly the favourable distributive effects of a lower inflation rate), they reach conclusions that are similar to the first of these results. In particular, this study shows that trade liberalization had an adverse distributive effect in the form of higher income differentials by qualification level; the increase in public spending in the 1990s had a similar effect. The first of these results agrees, furthermore, with those obtained by Birchenall (1997) who, using a probability functions methodology, finds that trade liberalization led to technological change that increased the demand for skilled labour in the seven main cities. For their part, Sánchez and Núñez (1999) find that, in the long term, increases in the unemployment rate and household size and real exchange rate depreciation increase the number of poor households, while improvements in educational levels, productivity and the terms of trade have favourable effects on the incidence of poverty in the main cities.

In summary, the studies that have been carried out largely associate the deterioration in income distribution experienced in the urban areas of Colombia in the 1990s with a far-reaching shift in earnings from work by qualification level, which has widened the income gap between qualified and unqualified workers, to the benefit of the former. The different hypotheses put forward have linked this increase with growth in relative demand for qualified labour resulting from trade liberalization, technical change and higher public spending; the last of these, however, has a favourable countervailing effect on secondary income distribution. Although distribution improved in rural areas, it did so against the background of a substantial loss of revenues resulting from deterioration in the rural terms of trade and the resultant crisis in commercial farming.

\section{Earnings and income distribution: general effects}

Table 10 shows the results of applying Paes de Barros' methodology (2000) to the National Household Surveys (NHS) for September 1991 and 1997. This methodology essentially consists in simulating what the distribution of income and poverty would have been in 1997 if 1991 labour market conditions had obtained. These conditions are the participation rate, the unemployment rate, the sectoral distribution of employment and earnings. Simulations are carried out for the na- 
TABLE 10

Colombia: Simulations of the effects of labour market changes on the Gini coefficient, 1991 and 1997

\begin{tabular}{lrrr}
\hline & National & Urban & Rural \\
\hline Gini 1991 & 0.5482 & 0.4977 & 0.4790 \\
Gini 1997 & 0.5650 & 0.5411 & 0.4409 \\
Difference & 0.0168 & 0.0434 & -0.0381
\end{tabular}

Labour force participation

\begin{tabular}{|c|c|c|c|}
\hline Simulated & 0.5595 & 0.5385 & 0.4498 \\
\hline Difference & 0.0055 & 0.0026 & -0.0089 \\
\hline Explanatory \% & 32.7 & 6.0 & -23.4 \\
\hline & \multicolumn{3}{|c|}{ Unemployment } \\
\hline Simulated & 0.5613 & 0.5365 & 0.4446 \\
\hline Difference & 0.0037 & 0.0046 & -0.0037 \\
\hline \multirow[t]{2}{*}{ Explanatory $\%$} & 22.1 & 10.7 & -9.8 \\
\hline & \multicolumn{3}{|c|}{ Sectoral composition of employment } \\
\hline Simulated & 0.5495 & 0.5314 & 0.4638 \\
\hline Difference & 0.0155 & 0.0097 & -0.0229 \\
\hline \multirow[t]{2}{*}{ Explanatory $\%$} & 92.1 & 22.3 & -60.2 \\
\hline & \multicolumn{3}{|c|}{ Relative wages } \\
\hline Simulated & 0.5504 & 0.5272 & 0.4295 \\
\hline Difference & 0.0146 & 0.0139 & 0.0114 \\
\hline \multirow[t]{2}{*}{ Explanatory $\%$} & 86.5 & 32.0 & 30.0 \\
\hline & \multicolumn{3}{|c|}{ Sequential } \\
\hline Simulated & 0.5361 & 0.5201 & 0.4376 \\
\hline Difference & 0.0289 & 0.0224 & -0.0414 \\
\hline Explanatory \% & 171.9 & 51.7 & -108.7 \\
\hline
\end{tabular}

Source: Calculated by the author on the basis of National Household Surveys.

tional, urban and rural totals, in two ways. Firstly, the effect of each of the labour market variables on income distribution is analysed in isolation. Then, their combined or sequential effect is analysed. ${ }^{9}$ In order to check the robustness of the values arrived at, the simulations were repeated a thousand times (Montecarlo experiment).

The simulations of the effects of each of the variables show that if 1991 labour market conditions had obtained in 1997, the Gini coefficient for the country would have been lower in all cases. Thus, the changes in the participation rate raised the Gini

\footnotetext{
${ }^{9}$ The sequential simulation first calculates the effects of changes in participation; once these results have been obtained the unemployment simulations are carried out, then these results are used to carry out the simulations of changes in the sectoral structure of employment. The results from these, lastly, are used to carry out the wage simulations.
}

coefficient by 0.0055 points (from an actual figure of 0.0168), those in the unemployment rate by 0.0037 , those in the sectoral composition of employment by 0.0155 and those in wage levels by 0.0146 . The results, then, reveal the greater relative influence exerted by the last two of these variables on the income concentration that took place during this period. The sequential simulation confirms the results. If the set of labour market conditions seen in 1991 had obtained in 1997, the Gini coefficient would have been even lower than it was in the earlier year: 0.536 as against 0.548 .

The results of the simulations of labour market conditions for urban areas are similar to those arrived at for the national total. The changes seen in the structure of employment and wages account for $22.3 \%$ and $32.0 \%$ of the changes in the Gini coefficient. The sequential simulation, meanwhile, accounts for $52 \%$ of the increase in the Gini coefficient in urban areas, i.e. 0.0224 out of a total increase of 0.0434 (from 0.497 to 0.541 ), which implies that the increase in income concentration was also contributed to by other factors not included in the labour market variables used for the simulations (among them being the greater heterogeneity of remuneration for workers with the same characteristics and changes in non-work incomes). In rural areas the Gini coefficient fell by 0.0381 (from 0.479 to 0.441 ). The changes in participation rates, in unemployment and, vitally, in the composition of employment (which is responsible for $60 \%$ of the change in the Gini) account for much of the decline in concentration. Changes in wage levels, however, show the opposite tendency.

The same methodology was applied in the case of changes in poverty levels, with results that were quite weak when compared with those obtained for income distribution. As table 11 shows, the percentage of poor households in the national total was $41.4 \%$ in 1997 as against $41.8 \%$ in 1991; in other words, the incidence of poverty was basically the same. If we look at the incidence of poverty in urban and rural areas separately, however, different results are obtained. Thus, the percentage of poor households fell in urban areas from $37.5 \%$ to $28.9 \%$ and increased in rural ones from $55.0 \%$ to $59.9 \%$. The simulation exercises show that if the participation rate, the unemployment rate and the sectoral composition of employment seen in $1991 \mathrm{had}$ obtained in 1997, the percentage of urban poor would have been lower than it actually was. In the case of wages, the simulation gives the opposite results.

In the case of the urban sector, however, this methodology has only a very limited ability to explain

THE LABOUR MARKET AND INCOME DISTRIBUTION IN COLOMBIA IN THE 1990S • JOSE ANTONIO OCAMPO, FABIO SANCHEZ 
TABLE 11

Colombia: Simulations of the effects of labour market changes on the population below the poverty line ( $\mathrm{PL})$, 1991 and 1997

\begin{tabular}{|c|c|c|c|}
\hline & National & Urban & Rural \\
\hline PL 1991 & 0.4180 & 0.3750 & 0.5500 \\
\hline PL 1997 & 0.4140 & 0.2890 & 0.5990 \\
\hline \multirow[t]{2}{*}{ Difference } & -0.0040 & -0.0860 & 0.0490 \\
\hline & \multicolumn{3}{|c|}{ Labour force participation } \\
\hline Simulated & 0.4081 & 0.2852 & 0.5893 \\
\hline Difference & -0.0059 & -0.0038 & -0.0097 \\
\hline \multirow[t]{2}{*}{ Explanatory \% } & -146.7 & -4.4 & -19.7 \\
\hline & \multicolumn{3}{|c|}{ Unemployment } \\
\hline Simulated & 0.4071 & 0.2824 & 0.5953 \\
\hline Difference & -0.0069 & -0.0066 & -0.0037 \\
\hline \multirow[t]{2}{*}{ Explanatory $\%$} & -171.6 & -7.6 & 7.6 \\
\hline & \multicolumn{3}{|c|}{ Sectoral composition of employment } \\
\hline Simulated & 0.3994 & 0.2811 & 0.5697 \\
\hline Difference & -0.0146 & -0.0079 & -0.0293 \\
\hline \multirow[t]{2}{*}{ Explanatory $\%$} & -365.8 & -9.2 & -59.9 \\
\hline & \multicolumn{3}{|c|}{ Relative wages } \\
\hline Simulated & 0.4156 & 0.2905 & 0.6001 \\
\hline Difference & 0.0016 & 0.0015 & 0.0011 \\
\hline \multirow[t]{2}{*}{ Explanatory \% } & 40.9 & 1.8 & 2.2 \\
\hline & \multicolumn{3}{|c|}{ Sequential } \\
\hline Simulated & 0.4020 & 0.2839 & 0.5703 \\
\hline Difference & -0.0120 & -0.0051 & -0.0287 \\
\hline Explanatory \% & -300.1 & -6.0 & -58.6 \\
\hline
\end{tabular}

Source: Calculated by the author on the basis of National Household Surveys.

the large reduction in poverty levels seen over the period analysed, which would suggest that there are other factors behind this trend. The work of Núñez and Sánchez (1999) shows that the fall in the percentage of people living in poverty in the seven main cities was fundamentally due to changes in the relative price of the basket of foodstuffs used to measure the poverty line. Of the 12 percentage points by which poverty declined, around 8.5 points are accounted for by a "price effect", in that the inflation rate of the poverty line basket of foodstuffs was lower than general inflation.

This methodology works better when it comes to accounting for changes in rural poverty. Thus, the results of the simulation show that if 1991 conditions in the rural labour market had obtained in 1997, the percentage of people living in poverty in the countryside would have been lower than it actually was. In particular, the variable that played the greatest part in the rise in the rural poverty percentage was the composition of employment, which accounts for $60 \%$ of the change $(0.0293$ points out of 0.0490$)$ in the incidence of poverty. The sequential simulation, which takes account of the set of labour market conditions obtaining in 1991, shows that these variables, taken all together, account for $59 \%$ of the rise in the incidence of rural poverty ( 0.0287 out of 0.0490 points).

\section{Analysis of labour market effects by income decile}

In order to consider in more detail which groups have been the most affected by the changes in the labour market, the simulation exercises were applied to each of the income deciles, in both rural and urban areas, for three variables: total income per capita, earnings per capita and incomes of those in work. The method was used to observe only the isolated effect of each of the labour market variables, without sequential simulation being carried out.

To provide a more accurate understanding of the results of the simulation exercises, table 12 gives some characteristics of the labour market by total per capita household income deciles. As can be seen, participation rates fell considerably between 1991 and 1997 in the two lowest income deciles and, to a lesser extent, in deciles 3 to 6 . In the upper income deciles, by contrast, the labour force participation rate was very similar in 1997 to what it had been in 1991. The pattern of the changes that occurred differs between urban and rural areas. While in urban areas the level of labour force participation fell in the poorest deciles and, to a lesser extent, in the richest ones, the rural participation rate increased in all the deciles, particularly the poorest ones, except for the top income decile, where it fell.

Between 1991 and 1997 the unemployment rate in the country as a whole rose by around three points. As table 12 shows, this increase was concentrated in the poorer income deciles, in both urban and rural areas. Between these years, earnings increased in all urban income deciles, although the increase was greater in the upper deciles. Earnings in rural areas, meanwhile, increased in the first four deciles and in decile 10, but fell in deciles 5 to 9 .

The effects of these labour market changes on total per capita income are shown in the left-hand panel of table 13. This shows that if 1991 labour force participation rates had obtained in 1997 , the poorer deciles, particularly decile 6 and below, would have increased their share of total income, which in turn would have

THE LABOUR MARKET AND INCOME DISTRIBUTION IN COLOMBIA IN THE 1990S • JOSE ANTONIO OCAMPO, FABIO SANCHEZ 
TABLE 12

Colombia: Labour market indicators by income deciles, 1991 and 1997

\begin{tabular}{|c|c|c|c|c|c|c|}
\hline & \multicolumn{2}{|c|}{ National total } & \multicolumn{2}{|c|}{ Urban } & \multicolumn{2}{|c|}{ Rural } \\
\hline & 1991 & 1997 & 1991 & 1997 & 1991 & 1997 \\
\hline \multicolumn{7}{|c|}{ Total participation rate $\%$} \\
\hline Decile 1 & 54.7 & 49.2 & 55.5 & 44.7 & 46.4 & 52.9 \\
\hline Decile 2 & 56.5 & 49.3 & 47.3 & 47.5 & 49.9 & 59.1 \\
\hline Decile 3 & 53.1 & 50.1 & 49.8 & 50.5 & 49.6 & 57.7 \\
\hline Decile 4 & 54.2 & 53.2 & 51.8 & 53.6 & 51.0 & 55.5 \\
\hline Decile 5 & 55.7 & 56.4 & 53.9 & 56.3 & 53.7 & 56.6 \\
\hline Decile 6 & 57.1 & 56.6 & 59.3 & 57.4 & 57.6 & 59.2 \\
\hline Decile 7 & 58.9 & 59.1 & 59.0 & 59.1 & 59.4 & 60.5 \\
\hline Decile 8 & 61.8 & 61.0 & 61.8 & 63.0 & 63.1 & 61.5 \\
\hline Decile 9 & 63.8 & 65.2 & 65.7 & 65.9 & 64.2 & 64.8 \\
\hline Decile 10 & 68.9 & 68.4 & 70.9 & 69.9 & 72.2 & 68.6 \\
\hline \multicolumn{7}{|c|}{ Unemployment rate $(\%)$} \\
\hline Decile 1 & 7.3 & 16. & 10.0 & 30.7 & 5.4 & 12.9 \\
\hline Decile 2 & 8.5 & 13.8 & 17.4 & 20.0 & 6.1 & 10.7 \\
\hline Decile 3 & 8.8 & 14.0 & 16.4 & 16.2 & 5.8 & 7.9 \\
\hline Decile 4 & 8.7 & 12.7 & 14.3 & 14.6 & 6.2 & 6.1 \\
\hline Decile 5 & 9.2 & 11.7 & 11.6 & 11.4 & 4.4 & 6.9 \\
\hline Decile 6 & 8.3 & 10.5 & 10.6 & 10.8 & 3.6 & 5.0 \\
\hline Decile 7 & 7.3 & 9.3 & 9.0 & 8.3 & 5.1 & 5.4 \\
\hline Decile 8 & 6.6 & 7.2 & 6.2 & 6.3 & 4.1 & 5.0 \\
\hline Decile 9 & 5.5 & 6.2 & 5.3 & 6.5 & 2.3 & 4.1 \\
\hline Decile 10 & 4.0 & 4.2 & 3.2 & 3.5 & 1.3 & 2.0 \\
\hline
\end{tabular}

Annual earnings per capita (1997 pesos)

\begin{tabular}{lrrrrrr} 
Decile 1 & 53677 & 44486 & 107299 & 136789 & 33033 & 54196 \\
Decile 2 & 61566 & 92052 & 124861 & 156049 & 42090 & 65726 \\
Decile 3 & 106358 & 124307 & 158767 & 171500 & 72840 & 83743 \\
Decile 4 & 130392 & 142184 & 185706 & 196359 & 98041 & 102341 \\
Decile 5 & 149833 & 166767 & 205006 & 207569 & 113091 & 110448 \\
Decile 6 & 167176 & 190167 & 217198 & 242878 & 122326 & 120235 \\
Decile 7 & 185970 & 223300 & 251955 & 263876 & 139755 & 121570 \\
Decile 8 & 211027 & 260934 & 286987 & 311433 & 146987 & 132912 \\
Decile 9 & 262110 & 348211 & 371026 & 417982 & 162367 & 150980 \\
Decile 10 & 601382 & 850812 & 781936 & 940018 & 186405 & 196843 \\
\hline
\end{tabular}

Source: Calculated by the author on the basis of National Household Surveys.

improved income distribution. This is consistent with table 12, which shows that labour force participation fell in the poorer deciles in the period being considered. The same thing happens with the simulated effect of the unemployment rate, although the greatest effect on income would have been seen mainly in deciles 2 to 7 . Meanwhile, the simulated effect of the changes in the sectoral composition of employment is to increase the share of deciles 5 and 6 and, particularly, decile 10 in total income per capita. Lastly, the simulated wage effect shows that if the national wage structure seen in 1991 had obtained in 1997, all the income deciles would have increased their share of total income except the richest decile, which is the one that would have lost out.

The simulations for urban areas of the effects of the labour market on changes in the shares of the different deciles confirm the results obtained in the previous section. If the labour market structure obtaining in 1991, in terms of the urban participation rate, unemployment rate, sectoral composition of employment and wages, had continued unchanged in 1997, the total income share of deciles 6 and below would have been higher, and this would have improved income distribution. This agrees with the results of table 12 , which show that deciles 6 and below experienced declines in labour force participation, rises in unemployment and increases in earnings that were smaller than those seen in the case of the higher income deciles. It can be seen, however, that it is deciles 3 to 6 , rather than the poorest ones, that would have benefited most.

In rural areas, if the 1991 rural labour force participation rate had obtained in 1997, the income shares of deciles 8 and below would have been lower, particularly where deciles 3 to 7 are concerned, while the shares of deciles 9 and 10 would have increased, implying a higher Gini coefficient. An effect similar to the above is seen when the effect of the unemployment rate is simulated. Simulation of the effects of the employment structure and wages on changes in the share of each decile in total rural income shows that this share would have declined for the poorest quintiles and increased for the richest ones in the countryside, which in turn would have meant higher income concentration. As regards the effect of the sectoral composition of employment, it transpires that these negative effects would have been greatest in deciles 2 to 4 , while the positive ones would have occurred mainly in deciles 8 to 10 . In the case of the effect of wages, the simulation shows that all deciles would have seen their income share decline, except for the richest one. The results confirm the trend in the rural labour market between 1991 and 1997, with greater increases in labour force participation and unemployment in the poorer deciles, higher earnings for deciles 5 and below and decile 10, and lower ones for deciles 6 to 9 .

The middle panel of table 13 contains the same set of simulations as was described earlier, carried out on this occasion, however, on per capita earnings instead of total income. The simulated effect of the participation rate and the unemployment rate on changes in the earnings shares of the different deciles shows results

THE LABOUR MARKET AND INCOME DISTRIBUTION IN COLOMBIA IN THE 1990S • JOSE ANTONIO OCAMPO, FABIO SANCHEZ 
TABLE 13

Colombia: Changes in shares of total per capita household income, per capita household earnings and income of the employed. Simulations of changes in the labour market, 1991-1997

(Percentages)

\begin{tabular}{|c|c|c|c|c|c|c|c|c|c|}
\hline & \multicolumn{3}{|c|}{$\begin{array}{c}\text { Change in share of total per capita } \\
\text { household income }\end{array}$} & \multicolumn{3}{|c|}{$\begin{array}{c}\text { Change in share of per capita } \\
\text { household earnings }\end{array}$} & \multicolumn{3}{|c|}{$\begin{array}{c}\text { Change in share of income } \\
\text { of the employed }\end{array}$} \\
\hline & National & Urban & Rural & National & Urban & Rural & National & Urban & Rural \\
\hline \multicolumn{10}{|c|}{ Labour force participation } \\
\hline Decile 1 & 0.05 & 0.01 & -0.03 & 0.01 & 0.03 & -0.01 & 0.06 & 0.03 & 0.04 \\
\hline Decile 2 & 0.06 & 0.02 & -0.07 & 0.03 & 0.04 & -0.02 & 0.08 & 0.06 & 0.17 \\
\hline Decile 3 & 0.05 & 0.05 & -0.09 & 0.02 & 0.03 & -0.03 & 0.11 & 0.07 & 0.13 \\
\hline Decile 4 & 0.08 & 0.04 & -0.11 & 0.01 & 0.06 & -0.03 & 0.11 & 0.01 & -0.01 \\
\hline Decile 5 & 0.06 & 0.04 & -0.11 & 0.04 & 0.06 & -0.05 & 0.06 & 0.01 & 0.04 \\
\hline Decile 6 & 0.04 & 0.03 & -0.10 & 0.05 & 0.04 & -0.07 & 0.10 & 0.19 & 0.08 \\
\hline Decile 7 & 0.00 & 0.00 & -0.11 & 0.04 & 0.04 & -0.02 & 0.22 & 0.05 & -0.10 \\
\hline Decile 8 & -0.02 & 0.00 & -0.01 & 0.02 & 0.04 & -0.02 & 0.09 & 0.06 & -0.07 \\
\hline Decile 9 & -0.04 & -0.04 & 0.19 & 0.01 & 0.04 & -0.03 & -0.02 & -0.02 & 0.40 \\
\hline Decile 10 & -0.27 & -0.16 & 0.45 & -0.24 & -0.39 & 0.29 & -0.83 & -0.47 & -0.69 \\
\hline \multicolumn{10}{|c|}{ Unemployment } \\
\hline Decile 1 & 0.04 & 0.01 & -0.03 & 0.00 & 0.01 & 0.00 & 0.07 & 0.07 & 0.06 \\
\hline Decile 2 & 0.07 & 0.02 & -0.07 & -0.01 & 0.01 & -0.01 & 0.12 & 0.11 & 0.12 \\
\hline Decile 3 & 0.08 & 0.04 & -0.09 & 0.00 & 0.02 & -0.02 & 0.14 & 0.16 & 0.18 \\
\hline Decile 4 & 0.08 & 0.06 & -0.09 & 0.00 & 0.01 & -0.03 & 0.18 & 0.15 & 0.20 \\
\hline Decile 5 & 0.09 & 0.05 & -0.13 & 0.01 & 0.00 & -0.01 & 0.18 & 0.20 & 0.18 \\
\hline Decile 6 & 0.05 & 0.05 & -0.11 & 0.01 & 0.03 & -0.02 & 0.22 & 0.19 & 0.22 \\
\hline Decile 7 & 0.03 & 0.03 & -0.10 & 0.02 & 0.00 & 0.00 & 0.18 & 0.20 & 0.21 \\
\hline Decile 8 & -0.04 & 0.02 & -0.01 & 0.00 & 0.02 & 0.05 & 0.18 & 0.15 & 0.07 \\
\hline Decile 9 & -0.07 & -0.02 & 0.17 & -0.02 & -0.03 & 0.06 & 0.10 & 0.03 & 0.09 \\
\hline Decile 10 & -0.33 & -0.27 & 0.48 & -0.01 & -0.08 & -0.03 & -1.37 & -1.25 & -1.33 \\
\hline \multicolumn{10}{|c|}{ Sectoral composition of employment } \\
\hline Decile 1 & -0.02 & 0.00 & -0.03 & 0.13 & 0.05 & -0.17 & 0.07 & 0.08 & 0.05 \\
\hline Decile 2 & -0.05 & 0.00 & -0.08 & 0.16 & 0.05 & -0.37 & 0.14 & 0.13 & 0.16 \\
\hline Decile 3 & -0.02 & -0.03 & -0.09 & 0.14 & 0.09 & -0.37 & 0.17 & 0.17 & 0.18 \\
\hline Decile 4 & -0.08 & 0.02 & -0.13 & 0.16 & 0.08 & -0.33 & 0.20 & 0.21 & 0.21 \\
\hline Decile 5 & 0.05 & 0.03 & -0.04 & 0.16 & 0.12 & -0.32 & 0.24 & 0.19 & 0.23 \\
\hline Decile 6 & 0.07 & -0.04 & -0.05 & 0.18 & 0.09 & -0.23 & 0.22 & 0.26 & 0.25 \\
\hline Decile 7 & -0.08 & -0.04 & -0.03 & 0.15 & 0.10 & -0.24 & 0.28 & 0.25 & 0.18 \\
\hline Decile 8 & -0.04 & -0.04 & 0.17 & 0.15 & 0.09 & -0.30 & 0.26 & 0.21 & 0.12 \\
\hline Decile 9 & -0.06 & -0.07 & 0.14 & 0.08 & 0.05 & -0.14 & 0.05 & 0.02 & 0.07 \\
\hline Decile 10 & 0.22 & 0.16 & 0.14 & -1.30 & -0.72 & 2.47 & -1.63 & -1.53 & -1.45 \\
\hline \multicolumn{10}{|c|}{ Relative wages } \\
\hline Decile 1 & 0.02 & 0.03 & -0.02 & 0.13 & 0.05 & -0.17 & 0.07 & 0.02 & 0.09 \\
\hline Decile 2 & 0.03 & 0.02 & -0.03 & 0.19 & 0.07 & -0.39 & 0.11 & 0.11 & 0.20 \\
\hline Decile 3 & 0.01 & 0.04 & -0.05 & 0.18 & 0.08 & -0.42 & 0.19 & 0.13 & 0.19 \\
\hline Decile 4 & 0.03 & 0.04 & -0.03 & 0.16 & 0.09 & -0.33 & 0.17 & 0.19 & 0.20 \\
\hline Decile 5 & 0.05 & 0.05 & -0.05 & 0.19 & 0.10 & -0.36 & 0.22 & 0.26 & 0.27 \\
\hline Decile 6 & 0.05 & 0.05 & -0.03 & 0.17 & 0.13 & -0.28 & 0.32 & 0.32 & 0.29 \\
\hline Decile 7 & 0.04 & 0.06 & -0.03 & 0.20 & 0.12 & -0.22 & 0.26 & 0.23 & 0.03 \\
\hline Decile 8 & 0.02 & 0.07 & -0.05 & 0.18 & 0.10 & -0.36 & 0.17 & 0.13 & 0.22 \\
\hline Decile 9 & 0.01 & 0.03 & -0.06 & 0.06 & -0.02 & -0.23 & -0.12 & -0.13 & 0.15 \\
\hline Decile 10 & -0.28 & -0.38 & 0.37 & -1.47 & -0.73 & 2.77 & -1.40 & -1.27 & -1.65 \\
\hline
\end{tabular}

Source: Calculated by the author on the basis of National Household Surveys.

THE LABOUR MARKET AND INCOME DISTRIBUTION IN COLOMBIA IN THE 1990S • JOSE ANTONIO OCAMPO, FABIO SANCHEZ 
similar to those obtained in the case of total income, although the values are generally lower, particularly where the simulation of the effects of the unemployment rate is concerned. By contrast, the simulated effects of employment composition and changes in wage earnings are greater. Thus, the table shows that the earnings shares of all the deciles, both in the country as a whole and in urban areas, would have been higher than they actually were, with the exception of the richest quintile (and only to a small degree in the case of decile 9 in urban areas). For rural areas, the effects of employment composition and the wage structure on rural income shares are also greater than those actually seen in the case of total incomes. The earnings shares of all the deciles would have been lower, except in the case of the richest decile, whose share would have been significantly higher.

\section{VI}

\section{Conclusions}

This paper has analysed the changes undergone by the labour market and income distribution over the period falling between 1991, when the reforms began, and 1997. During those years, economic growth was determined by the large swings experienced in aggregate domestic demand. The production structure, meanwhile, underwent appreciable changes: there was an increase in the relative weight of sectors producing goods and services that are not traded internationally, while there was a marked decline in tradable sectors, particularly agriculture and industry.

The repercussions of these changes in the labour market were significant. The ability of the economy to generate employment deteriorated considerably. This phenomenon, furthermore, is not a recent one, as it began to manifest itself during the spectacular surge in aggregate demand seen between 1992 and 1995. At that time it was not reflected in the unemployment rate because of the favourable trend in labour market participation. In sectoral terms, the decline in the ability of agriculture to generate employment was plain to see at the beginning of the decade, while in the case of industry it dates from the slowdown in that sector in the middle of the decade. These developments were offset during the upturn in the first half of the 1990s by the positive situation of non-tradable activities, but this favourable effect disappeared when
Meanwhile, the simulations of the effects of the labour market on the income shares of the different deciles of people in work, as shown in the right-hand panel of table 13, give results that, for the national total and for urban areas, are very similar to those obtained in the case of per capita earnings (central panel of the table), but that are obviously much more pronounced in the case of unemployment. The same does not hold true, however, for rural areas. In particular, the effects of the labour market on the different income recipients would appear to operate in the same direction in urban and rural areas, rather than in opposite directions as happens with the alternative simulations. To achieve a much more accurate understanding of why these contrary effects are seen, it would be necessary to carry out a detailed study of changes in the structure of rural households during the 1990s. the boom in domestic demand died down in the middle of the decade.

Those mainly affected by the adverse trend in employment were workers with a lower level of education. The changes undergone by the production structure, in fact, have hit the least well educated workers hardest, since it was these who were most affected by the loss of jobs in tradable sectors, while the rise in employment in non-tradable sectors tended to favour more highly educated workers. Technological change, meanwhile, has been capital-intensive and has reduced the need for labour at all levels of education, although less highly qualified workers have suffered most. The bias in labour demand towards better educated workers, resulting from economic liberalization, is also reflected in the increased profitability of the higher levels of education and in the improved incomes of these workers relative to others, which has had an adverse effect on urban income distribution.

Between 1991 and 1997 the country experienced a rise in income concentration as measured by the Gini coefficient, although this was the net outcome of contrary tendencies in urban and rural areas. Simulations of the income distribution effects of labour market changes between 1991 and 1997 show that the most significant effects in the country as a whole were

THE LABOUR MARKET AND INCOME DISTRIBUTION IN COLOMBIA IN THE 1990S • JOSE ANTONIO OCAMPO, FABIO SANCHEZ 
produced by the sectoral composition of employment and the wage structure, and to a lesser degree by changes in the labour force participation and unemployment rates. The same results are obtained for urban areas. The simulations for rural areas show that the changes which took place in the labour market between 1991 and 1997, and particularly the changes in the employment structure, helped to reduce income concentration. Movements in poverty, particularly the sharp decline seen in urban areas between 1991 and 1997, were dominated by other factors, above all the significant fall in the cost of the basic food basket, which obviously had opposite effects, in terms of income, in urban and rural areas.

\section{Bibliography}

Birchenall, J. (1997): Income Distribution, Human Capital and Economic Growth in Colombia, Archivos de macroeconomía, No. 70, Bogotá, Colombia, National Planning Department. Macroeconomic Analysis Unit.

Bernal, R., M. Cárdenas, F. Sánchez and J. Núñez (1998): El desempeño de la macroeconomía y la igualdad: 19761996, F. Sánchez (ed.), La distribución del ingreso en Colombia: tendencias recientes y retos de la política pública, Bogotá, Tercer Mundo Editores.

Colombia, Contraloría General de la República (1986): El problema laboral colombiano: diagnóstico, perspectivas y políticas. Informe final de la Misión de Empleo, Economía colombiana, No. 10, Bogotá.

Colombia, DANE (Departamento Administrativo Nacional de Estadística) (1999): Evolución de la economía colombiana. Primer trimestre de 1999, Bogotá.

Colombia, DNP (Departamento Nacional de Planeación)/UNDP (United Nations Development Programme) (1998): Informe de desarrollo humano para Colombia, 1998, Bogotá, Tercer Mundo Editores.

Farné, S., A. Vivas and J. Núñez (1998): La estabilidad laboral en el mercado de trabajo urbano en Colombia, 19841986, Bogotá, mimeo.

Henao, M.L. and A. Parra (1998): Educación y mercados de trabajo, Empleo: un desafío para Colombia, Bogotá, International Labour Organization (ILO).

Leivobich, J. and J. Nuñez (1999): The Microeconomics of Income Distribution Dynamics in Rural Colombia (1978-1988-1995), CEDE Document, No. 12, Bogotá, Centre for Economic Development Studies, August.

Núñez, J. and F. Sánchez (1999): Estimaciones trimestrales de la línea de pobreza y sus relaciones con el desempeño macroeconómico colombiano (1977-1997), Archivos de macroeconomía, No. 110, Bogotá, Colombia, National Planning Department. Macroeconomic Analysis Unit.

ILO (International Labour Oganization) (1998): Empleo: un desafío para Colombia, Bogotá, ILO/Ministry of Labour Project, mimeo.

Ocampo, J.A. (1997): Una evaluación de la situación fiscal colombiana, Coyuntura económica, vol. XXVII, No. 2, Bogotá, Fundación para la Educación Superior y el Desarrollo (FEDESARROLLO), June.

(1998): Una década de grandes transformaciones económicas (1986-1996), Nueva historia de Colombia, vol. VIII, Bogotá, Editorial Planeta.

Ocampo, J.A., M.J. Pérez, C. Tovar and F.J. Lasso (1998): Macroeconomía, ajuste estructural y equidad en Colombia: 1978-1996, E. Ganuza, L. Taylor and S. Morley (eds.),
Política macroeconómica y pobreza en América Latina y el Caribe, Madrid, Mundi Prensa.

Ocampo, J.A. and C. Tovar (1999): Price-Based Capital Account Regulations: The Colombian Experience, Financiamiento del desarrollo series, No. 87, Santiago, Chile, Economic Commission for Latin America and the Caribbean (ECLAC).

Paes de Barros, R. (2000): Methodological issues, paper presented for the project Liberalización de la balanza de pagos: efectos sobre el empleo, la distribución, la pobreza y el crecimiento, Buenos Aires, February.

Reina, M. and D. Yanovich (1998): Salud, educación y desempleo: diagnóstico y recomendaciones, Cuadernos, No. 4, Bogotá, FEDESARROLLO.

Ribero, R. and J. García (1996): Estadísticas descriptivas del mercado laboral masculino y femenino en Colombia: 1976-1995, Archivos de macroeconomía, No. 48, Bogotá, Colombia, National Planning Department. Macroeconomic Analysis Unit.

Sánchez, F. (ed.) (1998): La distribución del ingreso en Colombia: tendencias recientes y retos de la política pública, Bogotá, Tercer Mundo Editores.

Sánchez, F. and J. Núñez (1998): Educación y salarios relativos en Colombia, 1976-1995. Determinantes, evolución e implicaciones para la distribución del ingreso, F. Sánchez (ed.), La distribución del ingreso en Colombia: tendencias recientes y retos de la política pública, Bogotá, Tercer Mundo Editores.

(1999): Descentralización, pobreza y acceso a los servicios sociales. ¿Quién se benefició del gasto público en los noventa?, Coyuntura social, No. 20, Bogotá, FEDESARROLLO.

Taylor, L. (1998): Balance of payments liberalization: Effects on employment, distribution, poverty and growth, terms of reference for the project Liberalización de la balanza de pagos: efectos sobre el empleo, la distribución, la pobreza y el crecimiento, Santiago, Chile, United Nations Development Programme (UNDP)/ECLAC/InterAmerican development Bank (IDB)

Vélez, C.E., A. Kugler and C. Bouillón (1999): The reversal of inequality gains in urban Colombia, 1978-1995: a combination of persistent and fluctuating forces, Washington, D.C., World Bank, mimeo.

Villar, L. and H. Rincón (2000): The Colombian economy in the nineties: capital flows and foreign exchange regimes, paper presented at the conference Critical Issues in Financial Reform: Latin American/Caribbean and Canadian Perspectives, Toronto, University of Toronto, The Munk Centre for International Studies Programme on Latin America and the Caribbean, June. 